\title{
Woodland in a fluvio-lacustrine environment on the dry Mongolian Plateau during the late Paleocene: Evidence from the mammal bearing Subeng section (Inner Mongolia, P.R. China)
}

\author{
Jimmy Van Itterbeeck ${ }^{a, *}$, Pieter Missiaen ${ }^{b, c}$, Annelise Folie ${ }^{c, d}$, \\ Valentina S. Markevich ${ }^{\mathrm{e}}$, Dirk Van Damme ${ }^{\mathrm{b}}$, Guo Dian-Yong ${ }^{\mathrm{f}}$, Thierry Smith ${ }^{\mathrm{c}}$ \\ a Afdeling Historische Geologie, Katholieke Universiteit Leuven, Redingenstraat 16, B-3000 Leuven, Belgium \\ b Onderzoekseenheid voor Paleontologie, Vakgroep Geologie en Bodemkunde, Universiteit Gent, Krijgslaan 281-S8, B-9000 Gent, Belgium \\ c Département de Paléontologie, Institut Royal des Sciences Naturelles de Belgique, Rue Vautier 29, B-1000 Brussel, Belgium \\ d Département des Sciences de la Terre et de l'Environnement, Université Libre de Bruxelles, \\ Avenue Franklin-Roosevelt 50,B-1050 Bruxelles, Belgium \\ e Institute of Biology and Pedology, Far East Branch of the Russian Academy of Sciences, Vladivostok 690022, Russia \\ ${ }^{\mathrm{f}}$ Department of Natural Sciences, Inner Mongolia Museum, No. 2, Xinhua Street, Hohhot, Inner Mongolia 010020, China
}

Received 8 March 2006; received in revised form 4 July 2006; accepted 7 July 2006

\begin{abstract}
In the understanding of the global faunal turnover during the Paleocene-Eocene transition, an important role has been attributed to the Asian continent, although the Asian fossil record for this period is still incomplete. Here we present a multidisciplinary study of the Subeng section (Inner Mongolia, P.R. China), integrating sedimentological, stratigraphical and diverse palaeontological data, in order to reconstruct the palaeoenvironment and to enhance the understanding of the late Paleocene communities that once thrived on the Mongolian Plateau. The Subeng section starts with the Maastrichtian Iren Dabasu Formation directly covered by the late Paleocene Nomogen Formation. This Nomogen Formation is composed of typical lacustrine deposits at the base, covered by fluvio-lacustrine deposits at the top. Both types of deposits provided rich ostracod and charophyte assemblages, closest to those of the Naran Member, Naran Bulak Formation of Mongolia. Palynomorphs from the lake sediments suggest a local flora at Subeng more wooded and closed than reported from elsewhere in this region. The fluvio-lacustrine deposits of the Nomogen Formation have yielded a vertebrate fauna especially rich in mammals. The mammal fauna from Subeng is close to that from Bayan Ulan and typical for the Gashatan Asian Land Mammal Age. The presence of reworked pedogenic carbonate nodules and mud aggregates suggests an at least seasonally dry regional climate. Combined sedimentological and palaeontological data suggest the late Paleocene Nomogen Formation at Subeng was an isolated woodland in a fluvio-lacustrine environment, representing a locally humid environment on the semi-arid Mongolian Plateau. The mammal fauna reflects these differences and shows a number of relatives to mammals from the more humid northeastern Chinese biotic province as well as some North American immigrants. (C) 2006 Elsevier B.V. All rights reserved.
\end{abstract}

Keywords: Paleocene; Nomogen Formation; Gashatan; Erlian Basin; Inner Mongolia; China

\footnotetext{
* Corresponding author. Shell International Exploration and Pro-

duction, Kesslerpark 1, 2288GS Rijswijk, The Netherlands.

E-mail address: jvanitterbeeck@yahoo.co.uk (J. Van Itterbeeck).
} 


\section{Introduction}

The Paleocene/Eocene (P/E) boundary is a major turning point in Earth's history with sudden biotic changes in the marine and terrestrial realm. Across the northern hemisphere continents, a wave of modern mammal groups appeared at the beginning of the Eocene, at the expense of archaic forms that progressively became extinct.

These faunistic changes are associated with a sudden climate pulse, known as the Paleocene-Eocene Thermal Maximum (PETM) caused by a massive release of greenhouse gasses into the atmosphere. This event is reflected in the isotopic record by a consistent negative spike in the ${ }^{13} \mathrm{C} /{ }^{12} \mathrm{C}$ ratio and this carbon isotope excursion (CIE) has been chosen as the boundary criterion for the $\mathrm{P} / \mathrm{E}$ boundary (Gradstein et al., 2004 and references therein; Magioncalda et al., 2004).

Rich fossil mammal localities of the P/E-boundary interval have been intensely studied in North America (Gingerich, 2000, 2001, 2003) and Europe (Hooker, 1998; Smith, 2000). They have clearly demonstrated the sudden appearance of modern mammal groups over the entire northern hemisphere. However, the geographic origin of these modern mammals has not yet been discovered. Several hypotheses have been proposed and many of these attribute an important role for the Asian continent (Krause and Maas, 1990; Beard, 1998; Bowen et al., 2002; Ni et al., 2004), although the Asian fossil record for this period is still very incomplete. Therefore late Paleocene and early Eocene Asian mammal sites have been a popular research topic in recent years (Wang et al., 1998; Ting et al., 2003). Traditionally, the $\mathrm{P} / \mathrm{E}$ boundary in Asia is correlated to the boundary between the Gashatan and the Bumbanian Asian Land Mammal Ages (ALMA). The Gashatan faunas are best represented in the Gashato site and the Zhigden and Naran Member from Naran Bulak site in Mongolia and in the Bayan Ulan and Nomogen sites in Inner Mongolia, China. The best representatives for the Bumbanian ALMA are found within the Bumban Member of Naran Bulak in Mongolia, the Wutu Formation in East China and the Upper Lingcha Formation in South China (Ting et al., 2003).

The Subeng (Subon) locality was discovered in 1976, during field prospections in the Bayan Ulan and Nomogen area by Chinese scientists from the Institute of Vertebrate Paleontology and Paleoantropology (IVPP) and the Inner Mongolia Museum (IMM). Although Russell and Zhai (1987) mentioned the locality, no material from the Subeng locality was published. At the occasion of the Sino-Belgian Dinosaur expeditions (Bultynck and Dhondt, 1998, 1999, 2001), the Subeng region was re-explored by one of us (T.S.) in 1995 and a level rich in mammal remains was discovered. This level was sampled during fieldwork in 2000, 2001 and 2004, with the description of a new genus from the Subeng locality (Smith et al., 2004).

Although the Mongolian Plateau houses many interesting Paleogene mammal sites, only few sedimentological, micropalaeontological and paleoenvironmental studies have been conducted. The mammal bearing level at Subeng is situated within a well-exposed section that has also yielded numerous microfossils, molluscs, fish, amphibians, lizards, turtles, eggshells, and silicified wood fragments, which makes the section ideally suited for such studies. The present paper aims to give a summary of the Subeng section, integrating the sedimentological, stratigraphical and diverse palaeontological data. Thereby, we try to reconstruct the palaeoenvironment and to enhance the understanding of the late $\mathrm{Pa}$ leocene communities that once thrived on the Mongolian Plateau.

\section{Geological setting}

The Subeng section is situated near the ChineseMongolian border, within the Inner Mongolia autonomous province, P.R. China (Fig. 1, A). In this region an extensive sedimentary basin system comprises several basins, a.o. the Erlian Basin in which the studied section is located (Fig. 1, B). The sedimentary basin system in the Chinese-Mongolian border region is dominantly infilled with late Mesozoic sediments (Meng et al., 2003 and references therein). However upper Paleocene, Eocene and Oligocene strata are well developed in the Erlian Basin (Bureau of Geology and Mineral Resources of Nei Mongol autonomous region (BGMRNMAR), 1991).

The Subeng locality is situated $20 \mathrm{~km}$ southwest of the city of Erlianhot (Fig. 1, C). In an incline on the plateau, gullies have eroded the Quaternary cover, exposing the Tertiary sediments. In these outcrops three lithological units are observed (Fig. 1, D). The lower unit 1 is situated at the very base of the incline, and it is separated from the middle unit 2 by a hiatus that is obscured by runoff sediments. The transition from unit 2 to the upper unit 3 is continuously exposed.

The regional geological map (BGMRNMAR, 1991) identifies these three units respectively as the upper Cretaceous Iren Dabasu Formation and the Tertiary Nomogen and Bayan Ulan formations. Here however, we adopt the view of Meng et al. (1998), who no longer consider the Bayan Ulan beds as a separate formation, but as the upper part of the Nomogen Formation. 


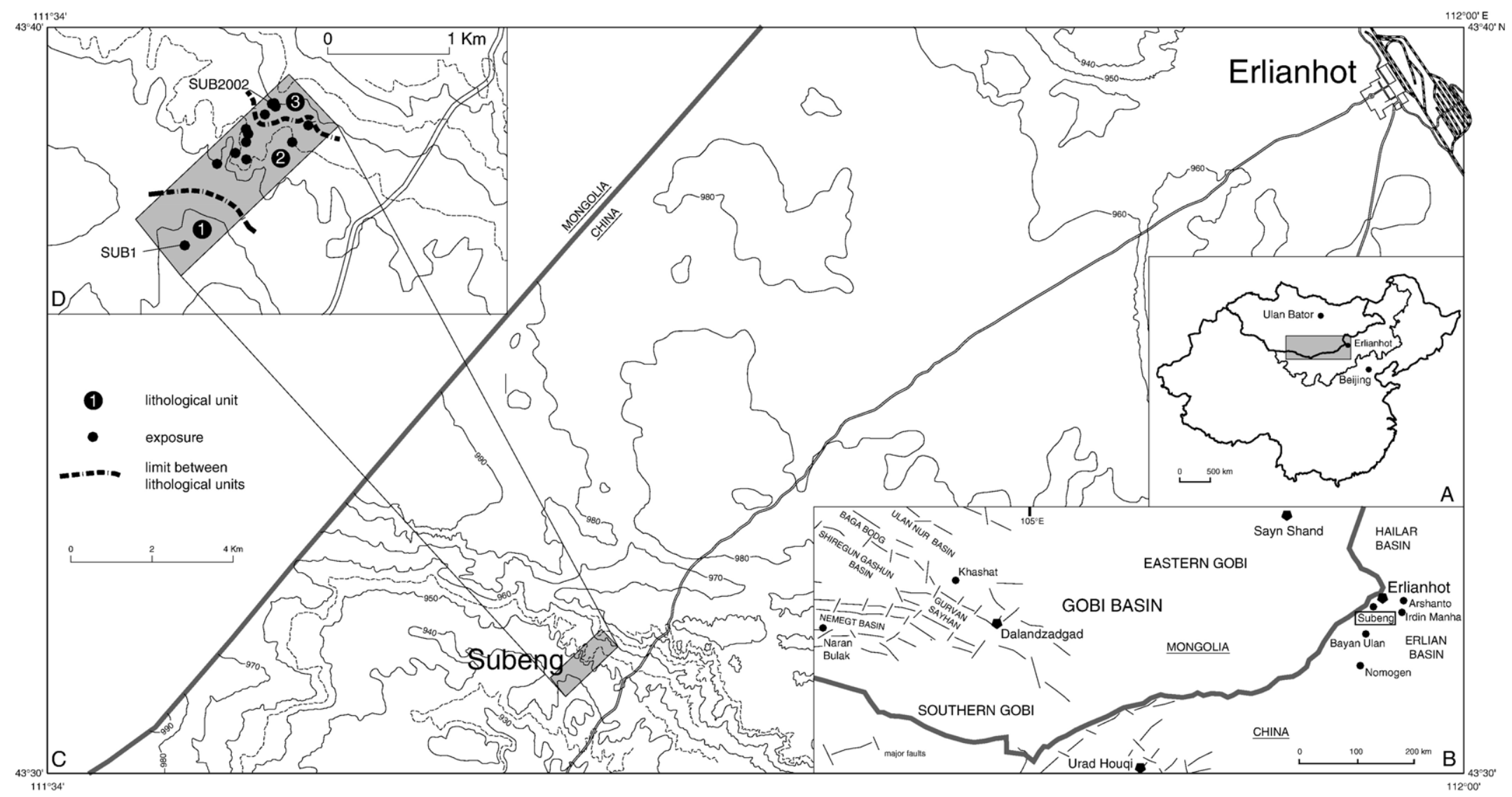

Fig. 1. A, inset map showing the location of the town Erlianhot in Inner Mongolia, China, grey rectangle indicates the area enlarged in B; B, map of the Gobi Basin with main cities ( $)$ and important mammal sites (๑); C, topographic map with the Subeng mammal site $20 \mathrm{~km}$ southwest from Erlianhot; D, detail of the Subeng section. 


\section{Sedimentary Geology}

\subsection{Unit 1 (Iren Dabasu Formation)}

Although this unit crops out in a vast area according to the geological map, it is only temporarily exposed in a man-made, 0.6-m deep trench at the base of the section. Two contrasting lithologies have been observed: a $0.05-$ $\mathrm{m}$ thick black, organic-rich clay covered by a white silt (Fig. 2). The fossil content of this exposure is limited to the palynomorphs retrieved from the organic-rich clay. This layer is interpreted as a histosol indicative of wetland conditions during deposition (Mack et al., 1993).

Conversely, in its type area around the Iren Nor salt lake (Berkey and Morris, 1927), the Iren Dabasu Formation presents only ferric and vertic gleyed calcisols (Van Itterbeeck et al., 2005).

\subsection{Unit 2 (Nomogen Formation)}

The green mudstones and white to yellowish limestones of unit 2 are exposed in the middle part of the Subeng section (Fig. 2). The limestones display an irregular fissility more or less parallel to the bedding plane. On these planes ostracod shells are abundant and can be observed with the naked eye. In thin section these limestones can be characterized as ostracodal packestones (Fig. 3.2). Charophyte gyrogonites occur in minor quantities while calcified charophyte stems have not been observed. The limestone near the top of the unit is somewhat different: it has a massive thickness of $20 \mathrm{~cm}$ and can be classified as an ostracodal wackestone (Fig. 3.3). Besides ostracods and charophytes, this layer has also yielded numerous gastropods but the vertebrate content is limited to rare fish teeth.

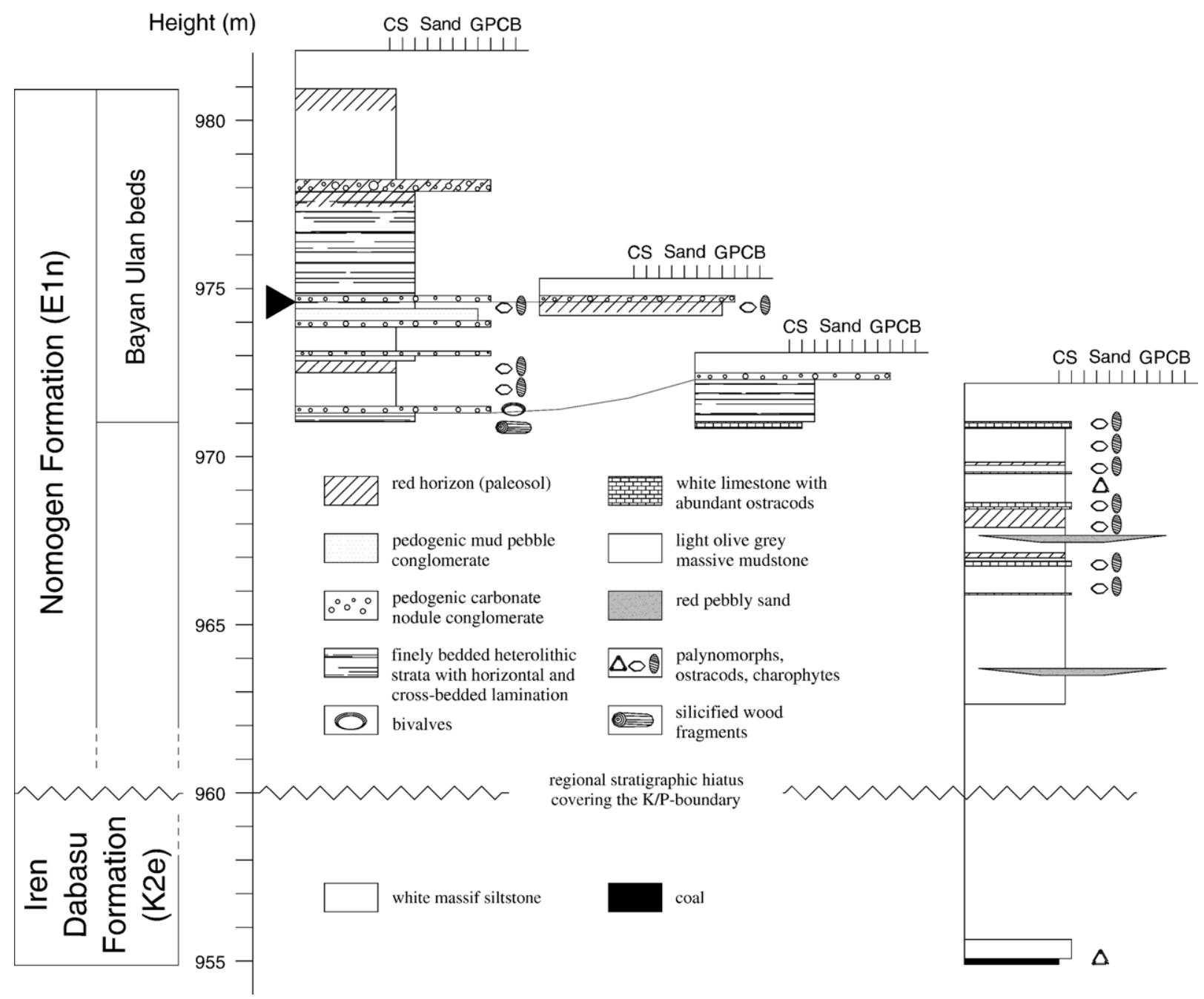

Fig. 2. Lithostratigraphic column of the Subeng section, $>$ indicates the mammal bearing horizon. 

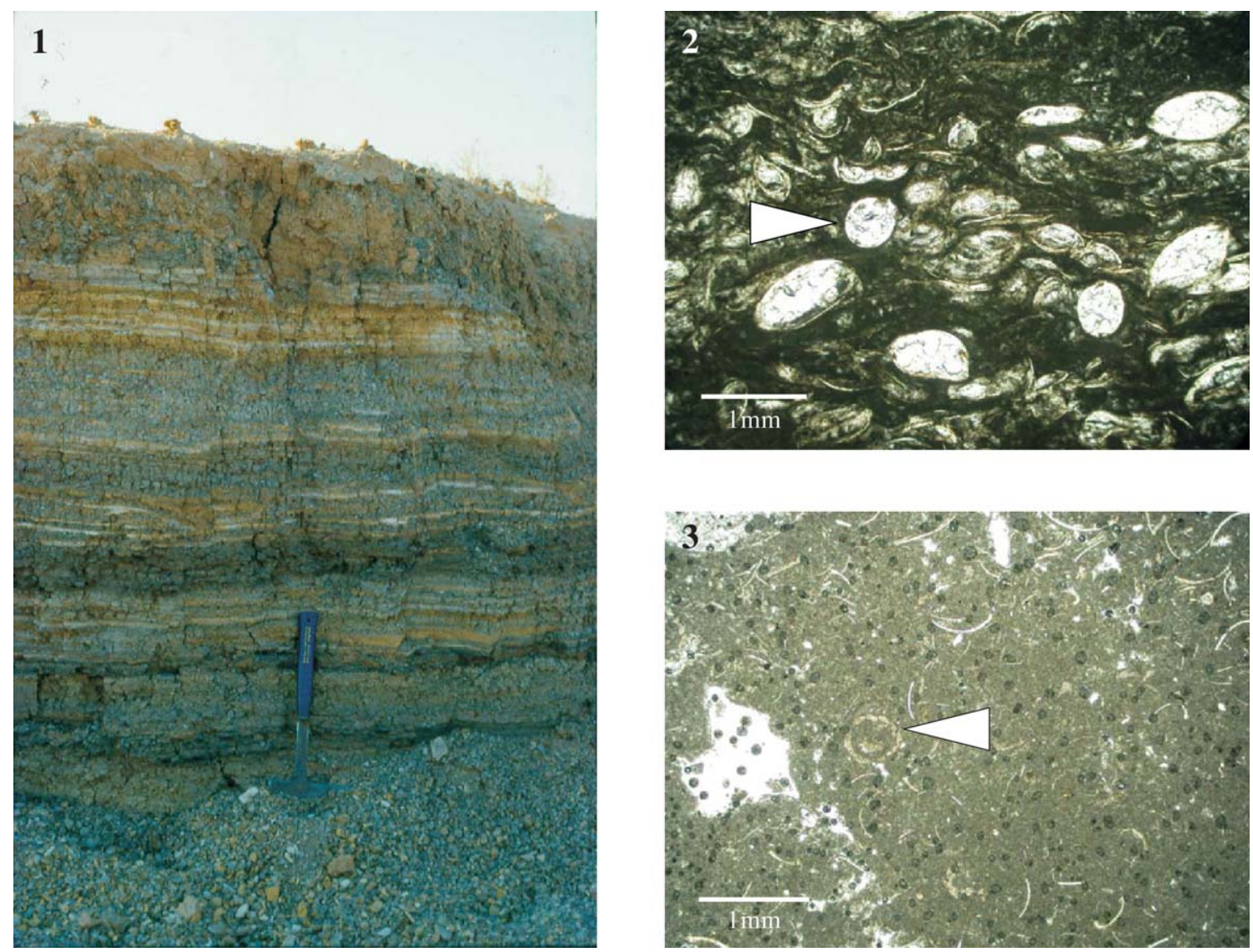

Fig. 3. Sediments of unit 2: 1, typical finely laminated strata with an alternation of greenish marls and white limestones, the dark organic-rich layers near the base have yielded a rich palynomorph assemblage; 2 , thin section of ostracodal packstone; 3 , thin section of ostracodal wackestone; arrows indicating charophytes.

The mudstones yield a similar fossil content, although in minor quantities, compared to the limestone layers. The mudstones are dominantly greenish, although black, organic-rich layers and red layers have been observed. The clay mineralogy of these mudstones has been defined by standard X-ray diffraction techniques which include untreated, glycolated and heated diffraction patterns. The dominant clay minerals are smectite and illite with minor kaolinite occurrences. There are no significant differences in clay mineralogy in the mud layers with a different colour.

Mudstones and limestones have been observed in two facies associations. In the first, they display a nearly undisturbed, fine cm-scale lamination (Fig. 3.1). It is within this association that the dark, organic-rich marls have been observed. The second association also shows an alternation of limestones and mudstones. However, in this case, both lithologies form uniform, massive beds with thicknesses ranging from 5 to $20 \mathrm{~cm}$ for the limestones and up to $120 \mathrm{~cm}$ for the mudstones. Within this second association, reddish mudstone layers have been observed, but dark, organic-rich layers are completely absent. Also within this second association two red, coarse pebbly sand lenses with a lateral extension of $2-3 \mathrm{~m}$ and a fining upward trend have been observed.

Both associations represent typical freshwater, lacustrine deposits, an interpretation corroborated by the fossil content of these layers (see Section 4). The rhythmically laminated sediments of association 1 are typical deeper water lacustrine deposits. The preservation of laminae indicates the absence of a bioturbating bottom fauna, which is typical for the deeper part of a stratified lake with anoxic bottom layers (Platt and Wright, 1991). The alternation of mudstone and limestone sedimentation is caused by an interplay between influx of siliciclastic material and biogenic carbonate production. During phases of high siliciclastic input in the lake, carbonate production is low due to the lowered light penetration in the suspension-rich waters and mudstones are deposited. During phases of low siliciclastic input, carbonate production is high due to 

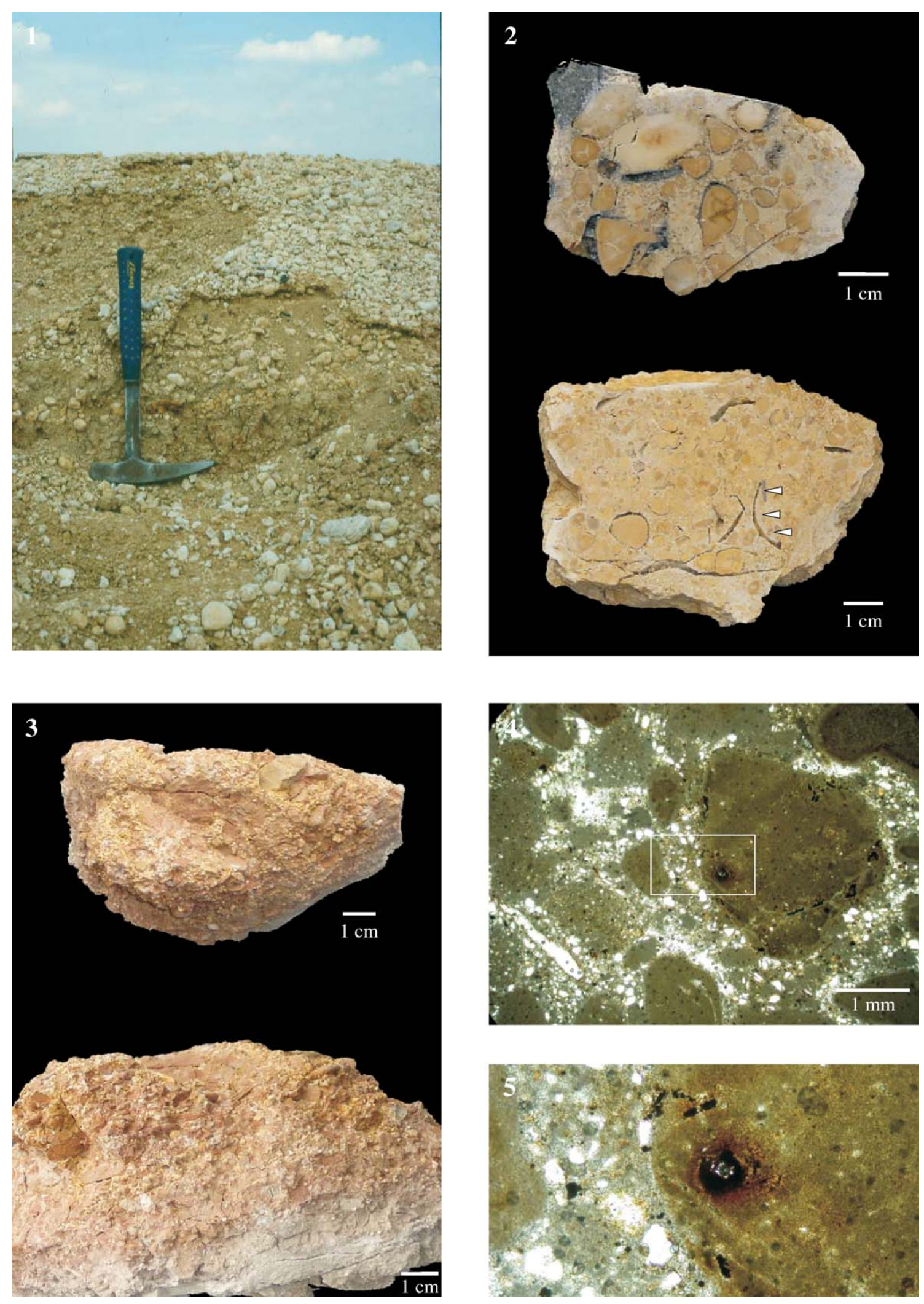
the enhanced light penetration in the clear lake waters resulting in limestone sedimentation. These processes play on different scales as can be deduced from Fig. 3.1. On a small scale, they cause the alternation of the separate mudstone and limestone laminae. On a larger scale, they cause groups of laminae that are dominated by one of the lithologies. For example, the top of this exposure is clearly dominated by limestone laminae compared to the rest of the outcrop.

The second association of mudstones and limestones is typical for shallow, nonstratified lacustrine environments. Bioturbation prevents the preservation of the smallscale lamination and only the large-scale variation (or dominance) is preserved. Due to fluctuations in the lake level, these shallow environments can temporarily be subaerially exposed resulting in the red coloring of the mudstones. No pedogenic features have been observed within the limestones. The red sandy lenses observed within this second association are interpreted as turbidity flows caused by large influxes of siliciclastic material within the lake. The most likely source is a larger river feeding the lake, but due to the limited exposure area it has not been observed.

\subsection{Unit 3 (Bayan Ulan Beds, Nomogen Formation)}

Unit 3 is exposed in the upper part of the section and displays the highest variability in both lithology and fossil content. The exposure of unit 3 is covered by a weathered horizon with a lag deposit enriched in silicified wood fragments, and as such its extent can easily be traced in the landscape. These fragments are poorly preserved but they can be attributed to gymnosperms (Gerrienne, pers. comm.). Unit 3 mainly consists of massive mudstones and finely bedded heterolithic sand-, silt- and claystones. The latter strata have a colour varying between yellowish gray (5Y8/1) and light olive gray $(5 \mathrm{Y} 6 / 1)$, and show both horizontal and crossbedded laminations. The massive mudstones are light olive gray (5Y5/2), and strongly resemble those of unit 2 in outward appearance, but clearly differ in clay mineralogy and fossil content. The unit 3 mudstones contain smectite, illite and kaolinite like the lacustrine mudstones, but also small amounts of chlorite. Their fossil content is dominated by charophytes, while the muds of unit 2 are dominated by ostracods.

The deposits described above are intercalated with pebble layers and some levels have a pebble fraction exclusively consisting of pedogenic carbonate nodules forming a conglomerate (Fig. 4.4, 4.5). On one occasion, such a conglomerate forms the basal infill of a channel with a lateral extent of $20 \mathrm{~m}$ and a maximum depth of $1.25 \mathrm{~m}$. The pedogenic nature of the pebbles has been proven by the occurrence of rhizocretons in thin sections. Most of the carbonate nodule layers are friable but some are well cemented and have proven to be also rich in bivalve molds. Other of these coarser levels contain a mixture of mud pebbles varying from 1 to $10 \mathrm{~mm}$ in size and sandsized carbonate particles (Fig. 4.3). The mud pebbles are well rounded with a flattened shape and a colour similar to the adjacent mudstones. The carbonate particles are white to yellowish and both biogenic (gyrogonites, ostracods, charophyte stems) and pedogenic in origin. A total of $1750 \mathrm{~kg}$ of these coarser layers were screenwashed for vertebrate fossils (Fig. 4.1).

As in unit 2, several red-coloured horizons have been recognized throughout unit 3 in all the different sediment types. They are often associated with slickensides and the presence of iron nodules and can be interpreted as palaeosols. The different coarse-grained lithologies in unit 3 indicate fluvial activity; and the large amount of gyrogonites and calcified charophyte stems are typical for marginal lacustrine environments, with still or slowly running waters (Corillion, 1975; Tappan, 1980). Unit 3 is therefore identified as marginal lacustrine/fluvial system that is a part of the lake during high lake levels. During low lake levels, soils are formed within the subaerially exposed sediments and fluvial activity reworks the altered sediments.

During the periods with the lowest lake levels soil formation is even observed within the sediments of unit 2 .

The fluvial system described here is not the trunk channel feeding the lake as its deposits do not contain the coarse siliciclastic grains observed in the unit 2 turbidite deposits. The mud pebbles deposited in unit 3 are clearly transported as bedload and not in suspension. Rust and Nanson (1989) were the first to describe this kind of bedload transport and they considered the mud pebbles as reworked pedogenic mud aggregates. The cooccurrence with reworked pedogenic carbonate nodules in Subeng section also clearly corroborates their pedogenic nature. No in situ mud aggregates or carbonate nodules have been observed and their main region of origin is unexposed. According to Rust and Nanson (1989), the mud aggregates form under a

Fig. 4. Sediments of unit 3: 1, Exposure of screenwashed mammal-bearing level, a typical pedogenic carbonate nodule conglomerate; 2 , cemented pedogenic carbonate nodule conglomerate with bivalve steinkerns (indicated by arrows); 3, Pedogenic mud aggregates; 4, Thin section through pedogenic carbonate nodule conglomerate, white rectangle indicates enlarged of 5; 5, detail of pedogenic carbonate nodule with root trace. 
Table 1

List of charophyte taxa observed in unit 3, Subeng section

Order Charales Lindley, 1836

Suborder Charineae Feist and Grambast-Fessard, 1991

Family Clavatoraceae Pia, 1927

Subfamily Clavatoroideae Pia, 1927 emend. Grambast, 1969

Genus Caenoclavator Wang and $\mathrm{Lu}, 1982$

Caenoclavator hubeiensis Wang and Lu, 1982

Family Characeae Agardh, 1824

Subfamily Charoideae Migula, 1897

Genus Grovesichara Horn af Rantzien, 1959

Grovesichara changzhouensis Huang and S. Wang in

Wang, 1978

Grovesichara kielani Karczewska and Ziembinska-

Tworzydlo, 1972

Genus Peckichara Grambast, 1957

Peckichara varians Grambast, 1957

Peckichara lefeldi Karczewska and Ziembinska-

Tworzydlo, 1973

Peckichara subsphaerica Lin and Z. Wang, 1982

Genus Neochara Z. Wang and Lin, 1978

Neochara huananensis Z. Wang and Lin, 1978

Genus Nemegtichara Karczewska and Ziembinska-

Tworzydlo, 1972

Nemegtichara prima Karczewska and Ziembinska-

Tworzydlo, 1972

Nemegtichara secunda Karczewska and Ziembinska-

Tworzydlo, 1972

Nemegtichara quarta Karczewska and Ziembinska-

Tworzydlo, 1972

Genus Gobichara Karczewska and Ziembinska-

Tworzydlo, 1972

Gobichara deserta Karczewska and Ziembinska-

Tworzydlo, 1972

Gobichara nigra Karczewska and Ziembinska-

Tworzydlo, 1972

Gobichara tenera Karczewska and Ziembinska-

Tworzydlo, 1972

Gobichara rubra Karczewska and Ziembinska-

Tworzydlo, 1972

Gobichara latielliptica Lu and Luo, 1990

Genus Sphaerochara Mädler, 1952 emend. Horn af

Rantzien, 1959 emend. Horn af Rantzien and Grambast, 1962 Sphaerochara minutissima (Mädler, 1955) n. comb.

Genus Collichara S. Wang and Z.R. Zhang, 1982 Collichara taizhouensis S. Wang and Z.R. Zhang, 1982 Collichara xiaohekouensis S. Wang and Zhang, 1982

Genus Microchara Grambast, 1959

Microchara cf. vestita Castel, 1969

Genus Pseudolatochara Z. Wang, 1978

Pseudolatochara ovatoides Huang and Zhang, 1984

Pseudolatochara sp.

Genus Maedleriella Grambast 1957

Maedleriella sp.

Genus Mesochara Grambast, 1952

Mesochara sp.

Genus Stephanochara Grambast, 1959

Stephanochara lauta (Liu, 1987) comb. nov.

Stephanochara cuniformis (Zhang, 1978) comb. nov.

Stephanochara stipitata (Liu, 1987) comb. nov.

Stephanochara grambasti (Karczewska and Ziembinska-

Tworzydlo, 1972) comb. nov.
Table 1 (continued)

\author{
Stephanochara grandiceps (Wang, 1981) comb. nov. \\ Genus Chara Linnaeus, 1753 \\ Chara spp.
}

climate with at least seasonally hot and dry periods in clay-rich layers containing at least a minor amount of swelling clays, the ideal conditions to generate vertisols. Indeed, the dominant clay mineral in these pebbles as in the rest of unit 3 is smectite and the palaeosol horizons do display vertic features like slickensides.

The reworked pedogenic carbonate nodules originate from calcretes that have been described from both Cretaceous (Van Itterbeeck et al., 2005) and Paleocene deposits in the other parts of the basin. In fact, these calcretic carbonate nodules have been used in other outcrops of the Nomogen Formation to locate the P/E boundary based on carbon isotopes (Bowen et al., 2005).

\section{Palaeontology}

\subsection{Charophytes}

The mammal-bearing horizon in the Subeng section has yielded a very rich assemblage of charophytes (see Table 1 for a complete list; see also Fig. 5). At the generic level the charophyte assemblage indicates a Paleocene to Eocene age. Seven genera, Gobichara, Nemegtichara, Peckichara, Collichara, Microchara, Pseudolatochara and Maedleriella have a stratigraphic range from the upper Cretaceous into the Eocene (Feist and Grambast-Fessard, 1982, Huang and Zhang, 1984; Huang and Zhao, 1989). The genera Grovesichara, Chara and Stephanochara are typical Cenozoic genera. From a geographical point of view, Nemegtichara, Gobichara, Collichara, Neochara, Caenoclavator are endemic to China and Mongolia while Grovesichara, Chara, Stephanochara and Peckichara have a cosmopolitan distribution.

One of the most abundant species is Grovesichara changzhouensis. This species is generally considered as a biostratigraphic marker of Paleocene to early Eocene strata in China (Tang and Di, 1991). Two specimens were attributed to Caenoclavator hubeiensis (Fig. 5, 11-13) that had thus far only once been observed in the lower Eocene (Wang and Lu, 1982). However, another species, C. naomugenensis has been reported from the late Paleocene Nomogen Formation (Liu, 1987). Caenoclavator is the only Cenozoic representative of the family Clavatoraceae; although the validity of the genus has been contested ( $\mathrm{Lu}, 1997)$, we continue to use it here 


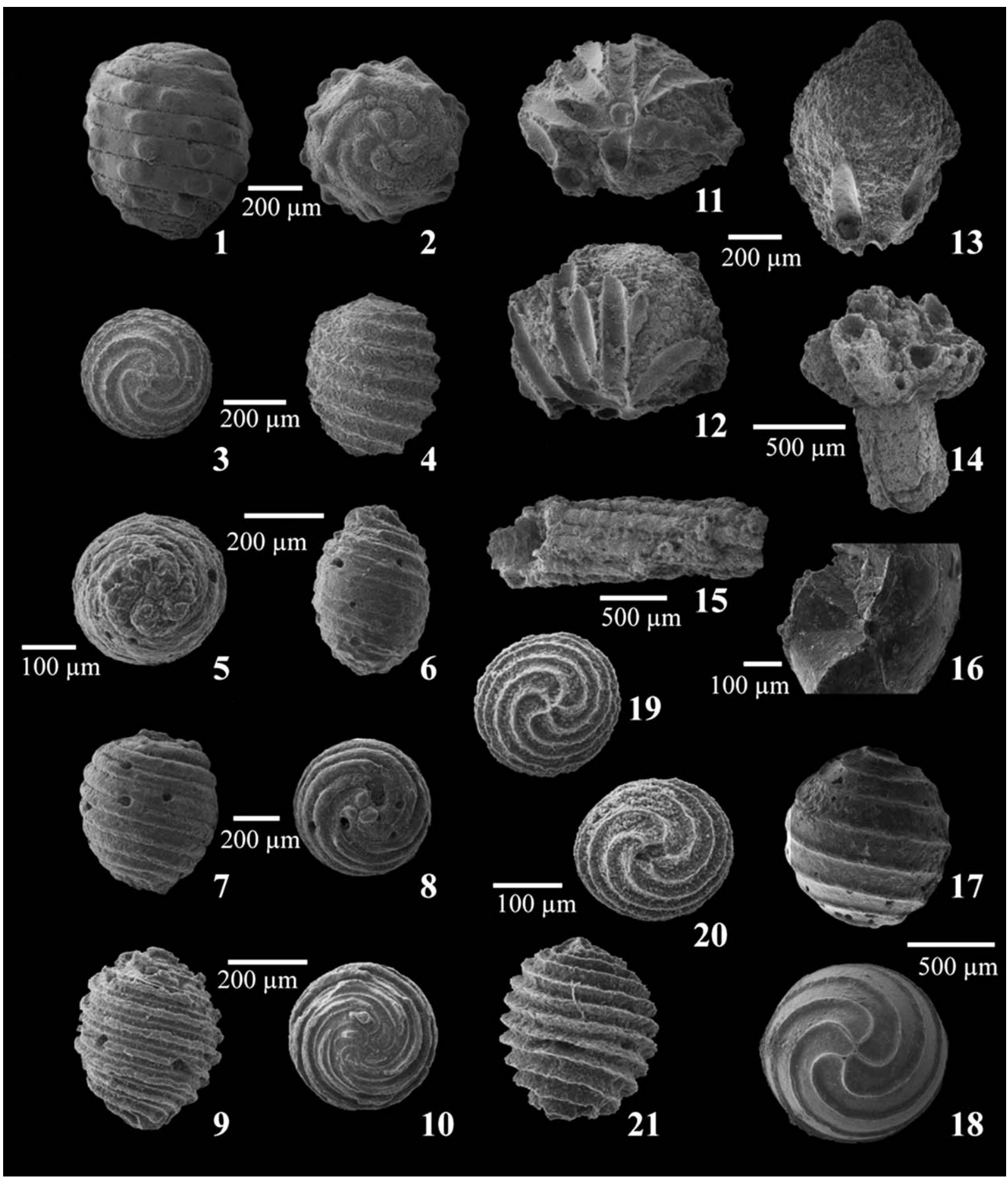

Fig. 5. Charophytes of the mammal bearing horizon: 1, Neochara huananensis, lateral view; 2, idem, apical view; 3, Nemegtichara prima, apical view; 4, idem, lateral view; 5, Collichara taizhouensis, apical view; 6, idem, lateral view; 7, Peckichara lefeldi, lateral view; 8, idem, apical view; 9 , Gobichara deserta, lateral view; 10, idem, apical view; 11, Caenoclavator hubeiensis, basal view; 12/13, idem, lateral view; 14/15, Charaxis sp.; 16, Grovesichara changzhouensis, detail of basal plate; 17, idem, lateral view, 18, idem, apical view; 19, Sphaerochara minutissima, apical view; 20, idem, basal view with composed basal plate; 21 , idem, lateral view. 
for lack of an alternative. The current material doesn't allow a detailed study of this genus.

The charophyte assemblage from unit 3 most closely correlates with that from the late Paleocene Naran Member of the Naran Bulak Formation (Nemegt Basin, Mongolia). From the 19 species in 9 genera present at Naran Bulak (Karczewska and Ziembinska-Tworzydlo, 1972), 12 species in 6 genera were also found at Subeng. So, the charophyte flora of the mammal-bearing horizon in the Subeng section clearly indicates the correlation of these beds with the Naran Member of the Naran Bulak Formation and suggests a late Paleocene age.

The charophyte flora of unit 2 is similar though fairly poor (both in specimens and species) compared with the flora of unit 3. The most important difference is the absence of Grovesichara changzhouensis.

The charophyte flora of the Nomogen and Iren Dabasu formations has been studied by Liu (1987). The data for this publication were compiled from different localities in the Shalamulun area in Inner Mongolia. For the Nomogen Formation, some of the data were gathered in a locality named 'Subeng' (Liu, 1987, p. 131-133), but any information on the exact location is lacking and it is unclear if Subeng in Liu (1987) equals the section studied in the present work. Liu (1987) considers the Nomogen Formation and the Bayan Ulan Formation as two separate formations, probably corresponding to unit 2 and unit 3 as described in the present work. Both levels as identified by Liu (1987) are very similar, differing mainly by the presence of Obtusochara laticonia Xinlun et al., 1978 and Maedlerisphaera in the Bayan Ulan 'Formation'. Although these two species are absent in our unit 3, the rest of our unit 3 assemblage is very similar in composition to that of the Bayan Ulan Formation sensu Liu, 1987.

\subsection{Ostracods}

The ostracods of unit 2 and unit 3 are very similar but unit 2 is richer in specimens. The ostracod assemblage of unit 3 (Bayan Ulan Beds, Nomogen Formation) at the Subeng mammal site consists of nine species belonging to six genera (Table 2; see also Fig. 6). The genus $\mathrm{Ca}$ ganella is endemic to Mongolia and is only known from the Paleocene (Khand, 2000, Fig. 1). The presence of the genus Cypris indicates that the age of the sediments can be no older than the Paleocene (Guan, 1988, Fig. 1) or even the late Paleocene (Khand, 2000, Fig. 1).

Seven of the nine ostracod species are shared with the Naran Member of the Naran Bulak Formation (Szczechura, 1971; Khand, 1976, 1987): Caganella oblonga,
Table 2

List of ostracod taxa observed in unit 3, Subeng section

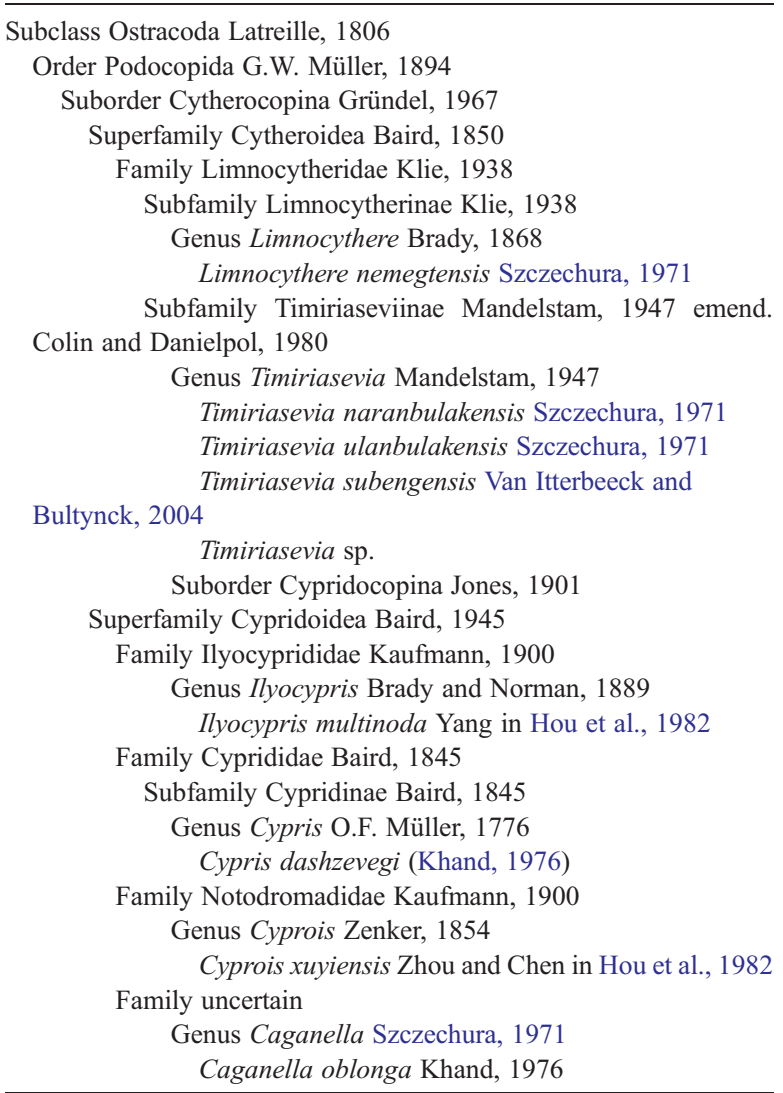

Timiriasevia subengensis, T. naranbulakensis, T. ulanbulakensis, Timiriasevia sp., Limnocythere nemegtensis and Cypris dashzevegi. However, from these seven species, only the latter two have been reported from other strata than the Naran Member. Limnocythere nemegtensis has been observed in the Paleocene Xhinzuang Formation and in the late Paleocene upper Shashi Formation, both in China. Cypris dashzevegi has often been misidentified as the recent African $C$. decaryi, and under this name it was considered typical for the lower Eocene of China (Van Itterbeeck and Bultynck, 2004 and references therein). The other two species (Ilyocypris multinoda, Cyprois xuyiensis) have been reported from levels 2-4 from the Funing Group, Jiangsu (Hou et al., 1982). Both the Naran Member of the Naran Bulak Formation and the Funing Group are considered to be late Paleocene in age, although sometimes an early Eocene age has been proposed for the uppermost part of the Funing Group (He et al., 1988).

The ostracod assemblage of the Bayan Ulan Beds at the Subeng site confirms the correlation of these beds with the Naran Member of the Naran Bulak Formation and also suggests a late Paleocene age. 


\section{ARTICLE IN PRESS}

J. Van Itterbeeck et al. / Palaeogeography, Palaeoclimatology, Palaeoecology xx (2006) $x x x-x x x$
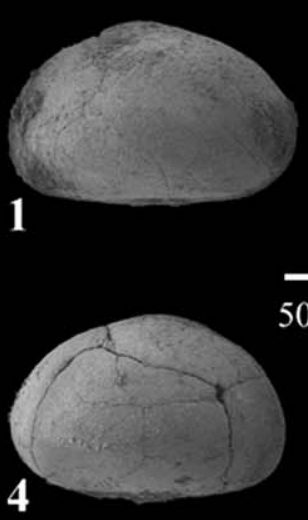

$500 \mu \mathrm{m}$

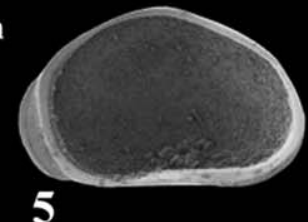

5

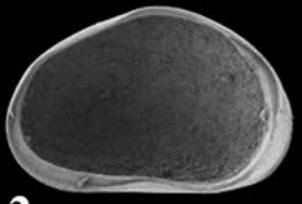

2
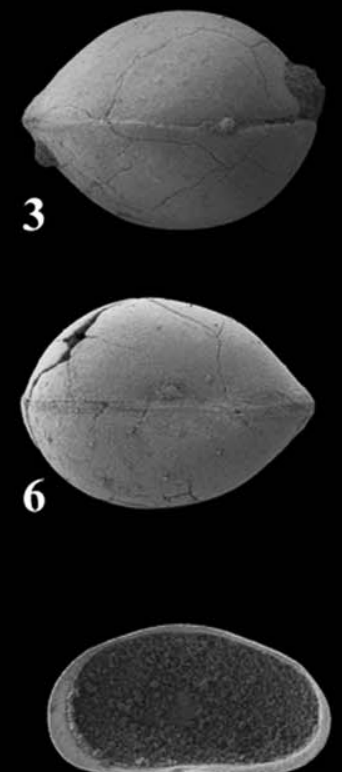

10

9

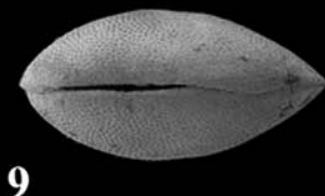

$200 \mu \mathrm{m}$

$200 \mu \mathrm{m}$
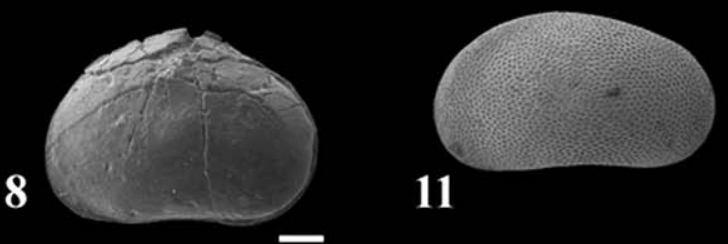

11
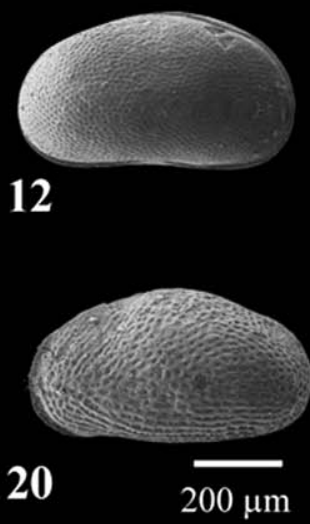

\section{$200 \mu \mathrm{m}$}

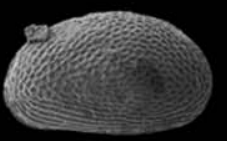

22

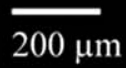

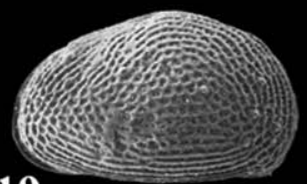

19

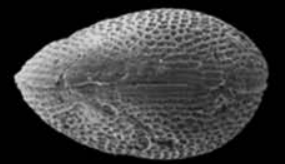

23

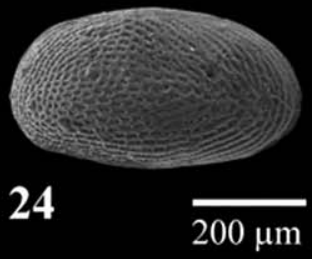

14

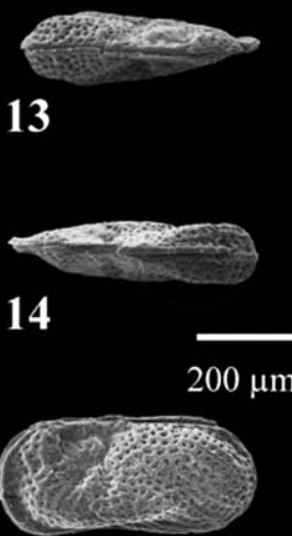

15

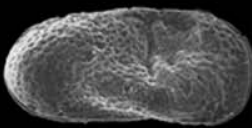

16

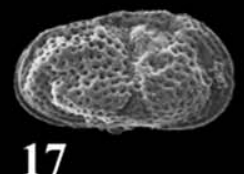

17
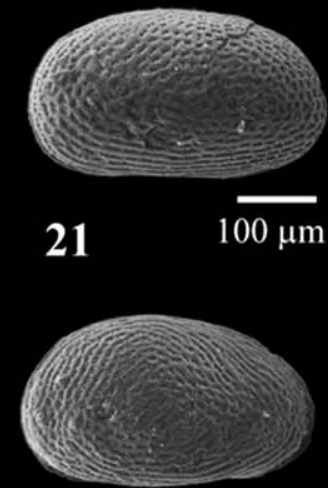

25

Fig. 6. Ostracods of the mammal bearing horizon: 1-6, Cypris dashzevegi: 1, adult, left valve, external view; 2, adult, left valve internal view; 3 , adult, carapace, dorsal view; 4, adult, right valve, external view; 5, adult, right valve, internal view; 6, adult, carapace, ventral view. 7, Ilyocypris multinoda, right valve, external view. 8, Cyprois xuyiensis, carapace, left external view. 9-12, Caganella oblonga: 9, carapace, dorsal view; 10, right valve, internal view; 11, left valve, external view; 12, carapace, right external view. 13-17, Limnocythere nemegtensis: 13, ठ7, carapace, dorsal view; 14 , 우, carapace, dorsal view; 15, $\sigma^{\top}$, left valve, external view; 16, 우, carapace, right external view; 17, juvenile, carapace, right external view. 18-19, Timiriasevia naranbulakensis: 18, carapace, dorsal view; 19, oొ, right valve, external view. 20, Timiriasevia sp., left valve, external view. 21, Timiriasevia ulanbulakensis, right valve, external view. 22-25, Timiriasevia subengensis: 22, 우, left valve, external view; 23, carapace, dorsal view; 24, ऽ?, carapace, right external view; 25 , 우, right valve, external view. 


\subsection{Palynomorphs}

\subsubsection{Unit 1 (Iren Dabasu Formation)}

According to the regional geological map, the sediments of unit 1 belong to the late Cretaceous Iren
Dabasu Formation and the taxonomically diverse palynospectrum of unit 1 is indeed typical for this age. The assemblage (Fig. 7) is dominated by gymnosperm pollen (approximately 70\%), mainly bisaccate pollen of the conifer families Pinaceae and Podocarpaceae.
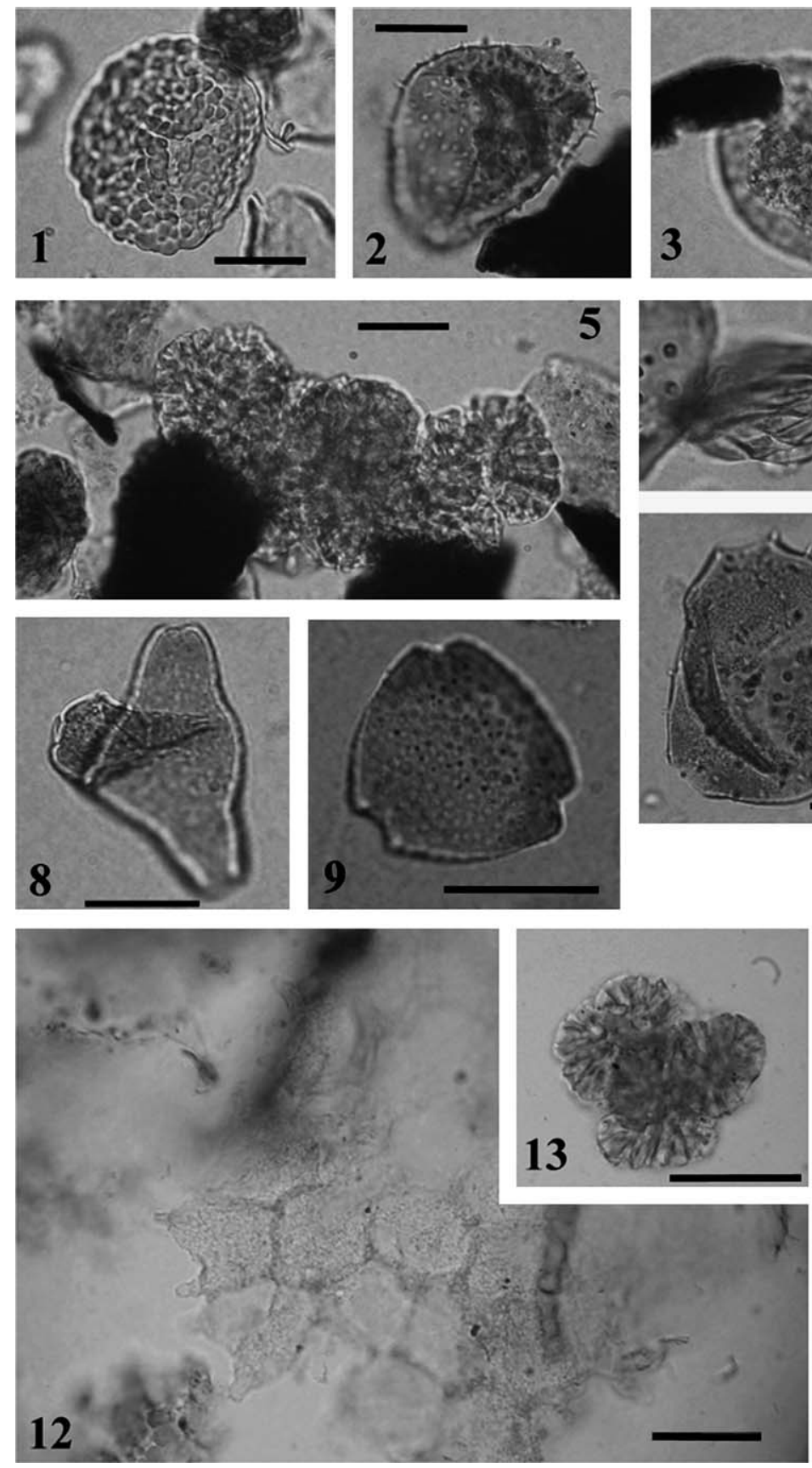

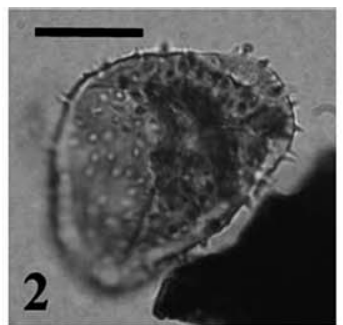

5
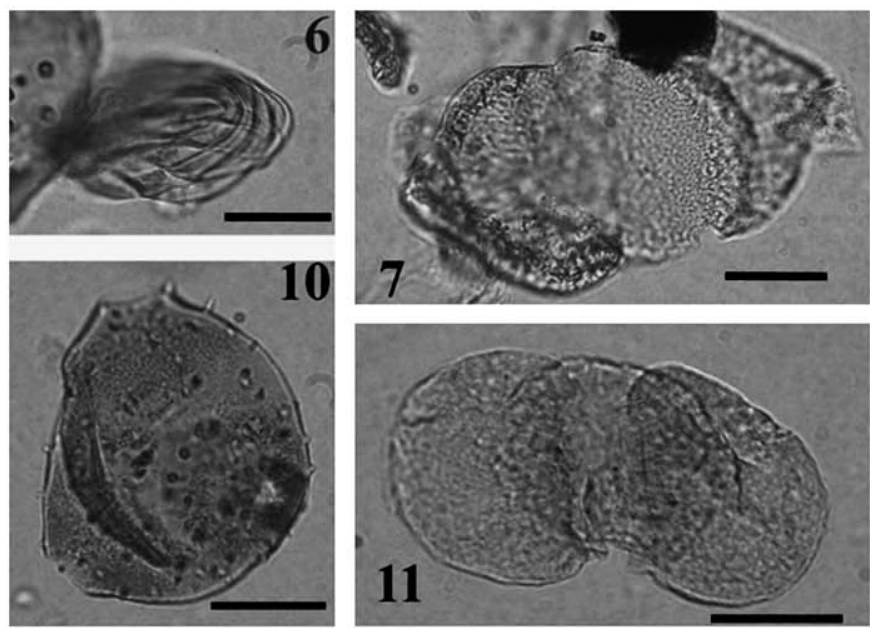

scale bar $=20 \mu \mathrm{m}$

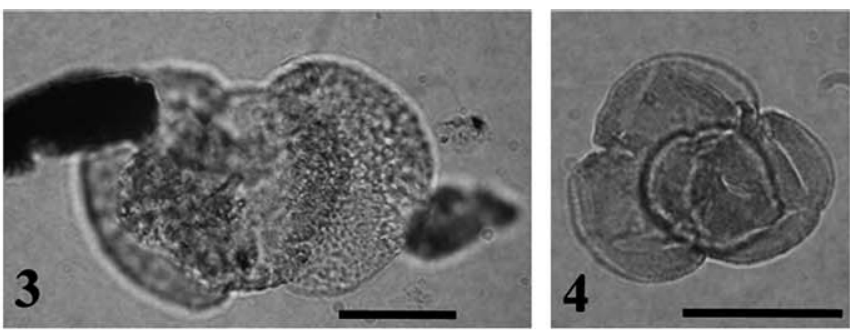

4
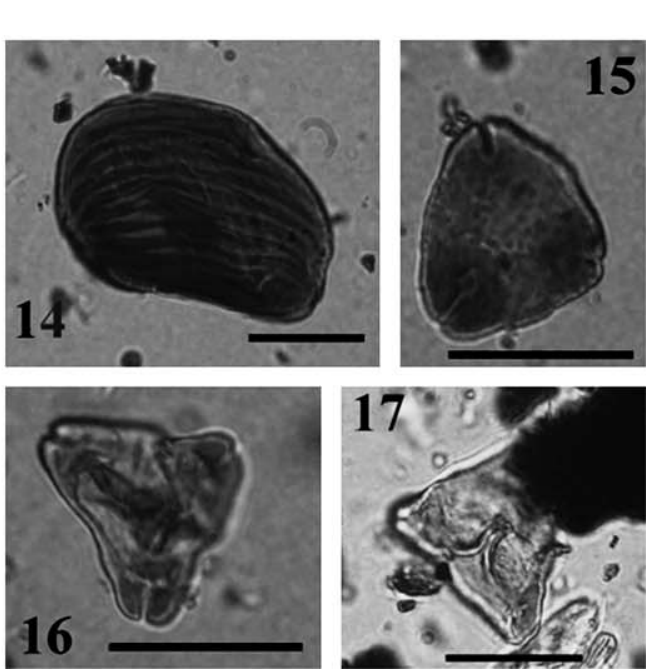

Fig. 7. Overview of the palynological assemblages in the Subeng section (scale bar $=20 \mu \mathrm{m})$ : 1-11 Palynomophs of unit 1: 1, Leptolepidites verrucatus; 2, Selaginella sp.; 3, Podocarpidites sp.; 4, 5, Botryococcus sp.; 6, Ephedripites sp.; 7, Pinuspollenites sp.; 8, Fibulapollis mirificus; 9 , Triatriopollenites echinatus; 10, 11, 12-17 Palynomorphs of unit 2: 12, Pediastrum sp.; 13, Botryococcus sp.; 14, Cicatricosisporites dorogensis; 15, Ocullopollis sp.; 16, Basopollis sp.; 17, Plicapollis plicatus. 
Gnetaceae, Taxodiaceae and Cupressaceae pollen are also common. The angiosperms are reasonably diverse, represented by 56 taxa (28\%). Most of them belong to the Normapolles-stemma although a few pollen of the Aquilapollenites-stemma have been recognized (Aquilapollenites, Fibulapollis). Spores only account for $2.7 \%$ of the spectrum.

Botryococcus is abundant, but it does not have any stratigraphical value (Batten and Grenfell, 1996 and references therein) and therefore has not been included in the census data. Nevertheless its abundance corroborates the interpretation of unit 1 as a wetland environment, as suggested also by the sedimentological data. Given this interpretation of unit 1 as a wetland, the low abundance of spores recorded in this assemblage is enigmatic (Table 3). Possibly the real diversity and abundance of ferns in the local vegetation is masked by the large dominance of bissacate pollen, in spite of our large sample (Frederiksen, 1985, p. 28-29).

Based on the distribution of Normapolles and Aquilapollenites type pollen, two palynofloral provinces are distinguished in the northern hemisphere during the Cretaceous, the Normapolles and Aquillapollenites provinces (Herngreen and Chlonova, 1981; Herngreen et al., 1996). Both pollen types only co-occur in the boundary zone between the two provinces, such as the Maastrichtian Ashut Formation of Northern Kazakhstan, and the Senonian palynological assemblages of Central Asia and the central part of West Siberia (Chlonova, 1961; Samoilovich, 1961; Polumiskova et al., 1966; Ponomarenko, 1966; Samoilovich, 1977). In China, this boundary runs from $38-39^{\circ} \mathrm{N}$ in the eastern coastal region to about $44^{\circ} \mathrm{N}$ in Inner Mongolia (Song and Huang, 1997). The Subeng section (N 43⒊ $50^{\prime \prime}, \mathrm{E} 111^{\circ} 44^{\prime} 04^{\prime \prime}$ ) is located directly in this boundary region, forming a new, well-documented site of cooccurrence and confirming the proposed broad ecotone zone between the two floristic provinces. The dominance of Normapolles over Aquilapollenites-type pollen in the Subeng section indicates a closer affinity with the Normapolles province.

Some Chinese authors divide China during the late Cretaceous and Paleocene into three floristic regions: the northeastern, northwestern and southern regions (Sun, 1979; Wang et al., 1990). The Subeng section is located in the boundary of the northeastern and northwestern region, but its palynospectrum best matches the latter. Characteristics for these late Cretaceous palynospectra of northwestern China are the presence of Normapolles like Basopollis, Extratriporopollenites and Triatriopollenites echinatus and secondly, the abundance of Ephedripites and some bisaccate pollen (Sun, 1979).
Table 3

Census data of palynomorphs from the Subeng section

\begin{tabular}{|c|c|c|c|c|}
\hline & \multicolumn{2}{|c|}{ Unit 1} & \multicolumn{2}{|c|}{ Unit 2} \\
\hline & \# & $\%$ & $\#$ & $\%$ \\
\hline \multicolumn{5}{|l|}{ Spores } \\
\hline Sphagnumsporites sp. & 1 & 0.16 & 1 & 0.30 \\
\hline Selaginella sp. & 1 & 0.16 & & \\
\hline Lycopodiumsporites sp. & 3 & 0.48 & & \\
\hline Leptolepidites verrucatus Couper, 1953 & 2 & 0.32 & 4 & 1.20 \\
\hline Osmundacidites sp. & 1 & 0.16 & & \\
\hline Leiotriletes sp. & 4 & 0.63 & 25 & 7.49 \\
\hline Dyctiophyllidites harrisii Couper, 1953 & & & 5 & 1.50 \\
\hline Cyathidites australis Couper, 1953 & 1 & 0.16 & 1 & 0.30 \\
\hline Cyathidites minor Couper, 1953 & & & 52 & 15.57 \\
\hline Gleicheniidites senonicus Ross, 1949 & & & 8 & 2.40 \\
\hline $\begin{array}{l}\text { Gleicheniidites laetus (Bolchovitina) } \\
\text { Bolchovitina } 1968\end{array}$ & & & 8 & 2.40 \\
\hline $\begin{array}{l}\text { Cicatricosisporites dorogensis Potonié } \\
\text { and Gelletich, } 1933\end{array}$ & & & 5 & 1.50 \\
\hline Klukisporites variegatus Couper, 1958 & & & 5 & 1.50 \\
\hline $\begin{array}{l}\text { Laevigatosporites ovoideis } \\
\quad \text { Takahashi, } 1961\end{array}$ & 4 & 0.63 & & \\
\hline $\begin{array}{l}\text { Laevigatosporites ovatus } \\
\text { Willson and Webster, } 194\end{array}$ & & & 14 & 4.19 \\
\hline
\end{tabular}

\section{Gymnosperms}

Ginkgocycadophytus sp.

Alisporites bilateralis Rouse, 1959

Pinuspollenites sp.

Piceapollenites sp.

Cedripites parvisaccatus (Sauer)

Krutzsch, 1971

Cedruspollenites sp.

Podocarpidites sp.

Taxodiaceaepollenites hiatus

(Potonié) Kremp, 1949

Taxodiaceaepollenites sp.

Cupressaceae

Ephedripites (Distachyapites) sp.

Ephedripites sp.

Gnetaeceaepollenites ovatus (Pierce)

Verbitzkaja, 1979

Classopollis sp.

$\begin{array}{rrrr}6 & 0.95 & 8 & 2.40 \\ & & 2 & 0.60 \\ 201 & 31.85 & & \\ 60 & 9.51 & & \\ & & 3 & 0.90 \\ & & & \\ 50 & 7.92 & & \\ 40 & 6.34 & & \\ & & 8 & 2.40 \\ & & & \\ 35 & 5.55 & 3 & 0.90 \\ 21 & 3.33 & & \\ 20 & 3.17 & & \\ 1 & 0.16 & 1 & 0.30 \\ 3 & 0.48 & & \\ & & & \\ & & 2 & 0.60 \\ \mathbf{4 3 7} & 69.26 & 27 & 8.08\end{array}$

\section{Angiosperms}

Tricolpites hians Stanley, 1965

Tricolpites sp.

Triporopollenites plicoides

Zaklinskaja, 1963

Triporopollenites sp.

Liliacidites variegatus Couper, 1953

Lixiodendron (=Palmae) sp.

Quercites sparsus (Martynova)

Samoilovich, 1961

Quercuspollenites sp.

Faguspollenites sp.

Platanuspollenites sp.
$4 \quad 0.63$

$7 \quad 2.10$

20.60

$4 \quad 1.20$

$4 \quad 0.63$

$4 \quad 0.63$

$2 \quad 0.60$

$2 \quad 0.32$

$3 \quad 0.48$

$2 \quad 0.32$ 
Table 3 (continued)

\begin{tabular}{|c|c|c|c|c|}
\hline & \multicolumn{2}{|c|}{ Unit 1} & \multicolumn{2}{|c|}{ Unit 2} \\
\hline & \# & $\%$ & \# & $\%$ \\
\hline \multicolumn{5}{|l|}{ Angiosperms } \\
\hline Caryapollenites sp. & 4 & 0.63 & 3 & 0.90 \\
\hline Castaneapollenites sp. & 1 & 0.16 & 12 & 3.59 \\
\hline Platycarya sp. & 2 & 0.32 & & \\
\hline Corylopsis crassa Lubomirova, 1965 & 2 & 0.32 & & \\
\hline Corylopsis sp. & 4 & 0.63 & & \\
\hline Alnuspollenites sp. & 1 & 0.16 & & \\
\hline Carpinuspollenites sp. & 1 & 0.16 & & \\
\hline Myricapollenites sp. & & & 1 & 0.30 \\
\hline $\begin{array}{l}\text { Anacolosidites acutullus } \\
\text { Cookson and Pike, } 1954\end{array}$ & 1 & 0.16 & & \\
\hline Sparganium sp. & 2 & 0.32 & & \\
\hline Ulmoideipites krempii Anderson, 1960 & 1 & 0.16 & & \\
\hline $\begin{array}{l}\text { Ulmoideipites planaeriformis } \\
\text { Anderson, } 1960\end{array}$ & 1 & 0.16 & & \\
\hline $\begin{array}{l}\text { Ulmoideipites tricostatus } \\
\text { Anderson, } 1960\end{array}$ & 2 & 0.32 & 2 & 0.60 \\
\hline Campanulaceae & 8 & 1.27 & & \\
\hline Caprifoliaceae & 10 & 1.58 & & \\
\hline Eleagnaceae & 1 & 0.16 & & \\
\hline Ericaceae & 1 & 0.16 & & \\
\hline Hamamelidaceae & 1 & 0.16 & & \\
\hline Menispermaceae & 1 & 0.16 & & \\
\hline Rubiaceae & & & 3 & 0.90 \\
\hline Elytranthe striatus Couper, 1953 & 1 & 0.16 & & \\
\hline $\begin{array}{l}\text { Proteacidites xiningensis } \\
\quad \text { Sun, Zhao and He, } 1980\end{array}$ & 4 & 0.63 & & \\
\hline $\begin{array}{r}\text { Aquilapollenites subtilis } \\
\text { Mtchedlishvili, } 1961\end{array}$ & & & 1 & 0.30 \\
\hline Aquilapollenites sp. & 1 & 0.16 & & \\
\hline Parviprojectus sp. & & & 1 & 0.30 \\
\hline $\begin{array}{l}\text { Fibulapollis mirificus (Chlonova) } \\
\text { Chlonova, } 1961\end{array}$ & 15 & 2.38 & 2 & 0.60 \\
\hline Basopollis spp. & 30 & 4.75 & 4 & 1.20 \\
\hline $\begin{array}{l}\text { Complexiopollis praeatumescens } \\
\text { Krutzsch, } 1959\end{array}$ & 8 & 1.27 & & \\
\hline Complexiopollis sp. & 11 & 1.74 & & \\
\hline $\begin{array}{l}\text { Extratriporopollenites rostratus } \\
\text { Scarby, } 1968\end{array}$ & 5 & 0.79 & & \\
\hline $\begin{array}{l}\text { Extratriporopollenites aff. vestifex } \\
\text { Pflug, } 1953\end{array}$ & 5 & 0.79 & & \\
\hline Extratriporopollenites sp. & 2 & 0.32 & 2 & 0.60 \\
\hline Interpollis heteroporatus Krutzsch, 1961 & & & 3 & 0.90 \\
\hline $\begin{array}{l}\text { Nudopollis terminalis } \\
\quad \text { (Thomson and Pflug) Pflug, } 1953\end{array}$ & 3 & 0.48 & & \\
\hline $\begin{array}{l}\text { Nudopollis thiergarti (Thomson and } \\
\text { Pflug) Pflug, } 1953\end{array}$ & 3 & 0.48 & & \\
\hline $\begin{array}{l}\text { Oculopollis praedicatus } \\
\quad \text { Weyland and Krieger, } 1953\end{array}$ & & & 35 & 10.48 \\
\hline Oculopollis sp. & & & 32 & 9.58 \\
\hline $\begin{array}{l}\text { Plicatopollis plicatus (Potonié) } \\
\quad \text { Krutzsch, } 1962\end{array}$ & & & 31 & 9.28 \\
\hline $\begin{array}{l}\text { Sporopollis trisulcatus Zaklinskaja, } \\
1963\end{array}$ & 6 & 0.95 & & \\
\hline Sporopollis peneserta Pflug, 1953 & & & 2 & 0.60 \\
\hline $\begin{array}{l}\text { Thomsonipollis magnificus (Thomson } \\
\text { and Pflug) Krutzsch, } 1960\end{array}$ & 1 & 0.16 & & \\
\hline
\end{tabular}

Table 3 (continued)

\begin{tabular}{|c|c|c|c|c|}
\hline & \multicolumn{2}{|c|}{ Unit 1} & \multicolumn{2}{|c|}{ Unit 2} \\
\hline & \# & $\%$ & \# & $\%$ \\
\hline \multicolumn{5}{|l|}{ Angiosperms } \\
\hline $\begin{array}{l}\text { Trudopollis cf. platoides (Pflug) } \\
\quad \text { Krutzsch, } 1967\end{array}$ & 2 & 0.32 & & \\
\hline Trudopollis sp. & 11 & 1.74 & & \\
\hline Vacuopollis sp. & & & 25 & 7.49 \\
\hline $\begin{array}{l}\text { Triatriopollenites echinatus } \\
\text { Sun and Zhang, } 1980\end{array}$ & 2 & 0.32 & & \\
\hline $\begin{array}{l}\text { Triatriopollenites plicatus } \\
\text { Thomson and Pflug, } 1953\end{array}$ & 1 & 0.16 & & \\
\hline $\begin{array}{l}\text { Kuprianipollis santaloides } \\
\quad \text { (Zaklinskaja) Komarova, } 1980\end{array}$ & & & 3 & 0.90 \\
\hline $\begin{array}{l}\text { Kuprianipollis elegans } \\
\quad \text { (Zaklinskaja) Komarova, } 1980\end{array}$ & & & 2 & 0.60 \\
\hline \multirow[t]{3}{*}{ Plananthus sp. } & 3 & 0.48 & & \\
\hline & 177 & 28.05 & 179 & 53.59 \\
\hline & 631 & 100.0 & 334 & 100.0 \\
\hline
\end{tabular}

\subsubsection{Unit 2 (Nomogen Formation)}

The palynological assemblage of unit 2 is completely different from that observed in unit 1 (Fig. 7). Gymnosperms make up $8 \%$ of the assemblage. They are dominated by Taxodiaceae and Ginkgocycadophytus while bisaccate pollen are nearly absent (Table 3). Angiosperm pollen are dominant but their diversity is reduced and they are dominated by triporate pollen, mainly by the Normapolles genera Oculopollis and Vacuopollis ( $>27 \%$ ). This extinct group is believed to be part of the Fagales (Sims et al., 1999; Friis et al., 2003). Spores occur fairly frequent with 13 species of ferns representing $38 \%$ of the total assemblage.

Because of the high abundance of organic matter in unit 2, palynomorphs were counted in oxidized slides. In the unoxidized slides, we also identified the freshwater algae Botryococcus sp. and Pediastrum sp. Their presence corroborates the sedimentological interpretation of unit 2 as lake sediments. Compact colonies of $\mathrm{Pe}$ diastrum are known since the early Cretaceous, but the first perforated forms are of Eocene age (Batten, 1996). All the Pediastrum colonies observed in unit 2 are of the compact form, not conflicting the inferred Paleocene age.

The palynological assemblage of unit 2 at Subeng has all the characteristics of a typical Paleocene assemblage in this region with a dominance of Normapolles, some relicts of dominant Cretaceous forms like Aquilapollenites and Fibulapollis and very few modern taxa like Castaneapollenites.

During the Paleocene, China is subdivided into 2 floristic provinces (Song, 1996, Fig. 2). Unlike the Northeastern region, the Northwestern floristic province 
is characterized by the dominance of Ephedripites and the abundant occurrence of Normapolles. The Nomogen Formation lies within the Northwestern floristic province, and indeed such palynological assemblages have been described from the Caomuhao gypsum mine in Inner Mongolia (Song and Zhang, 1990). It led these authors to the conclusion that the Mongolian Plateau had a savannah-like vegetation under a semi-arid, subtropical climate with local woodlands during the late Paleocene. The absence of Ephedripites, a known xerophyte, indicates that the Subeng section represents such a woodland. This interpretation is corroborated by the high abundance of ferns and the sedimentology, both indicating a humid local environment.

\subsection{Mollusca}

One of the pedogenic carbonate nodule conglomerate layers of unit 3 (Fig. 2) has yielded 12 bivalve molds, most of them articulated. All specimens (Fig. 8) belong to the exclusively freshwater family Unionidae, but preservation of the specimens limits their identification to the genus level. Most specimens can be attributed to Cuneopsis Simpson, 1900, a rare extant genus represented by five species in southern China and Vietnam. Fossil species of Cuneopsis have been described from upper Cretaceous deposits of Mongolia (Martinson, 1982 , p. 60-61). One specimen probably belongs to Acuticosta Simpson, 1900, nowadays represented by two species in China. The size, form and proportions of this specimen resemble A. chinensis (Lea, 1868) but more material is needed for a positive identification. One partial specimen probably represents a species of Lamprotula Simpson, 1900, an extant genus represented by 14 species. In spite of their occurrence in channel deposits, the dominance of articulated shells is indicative of a calm environment and limited transport. The optimal unionid habitat is a clean, well oxygenated,
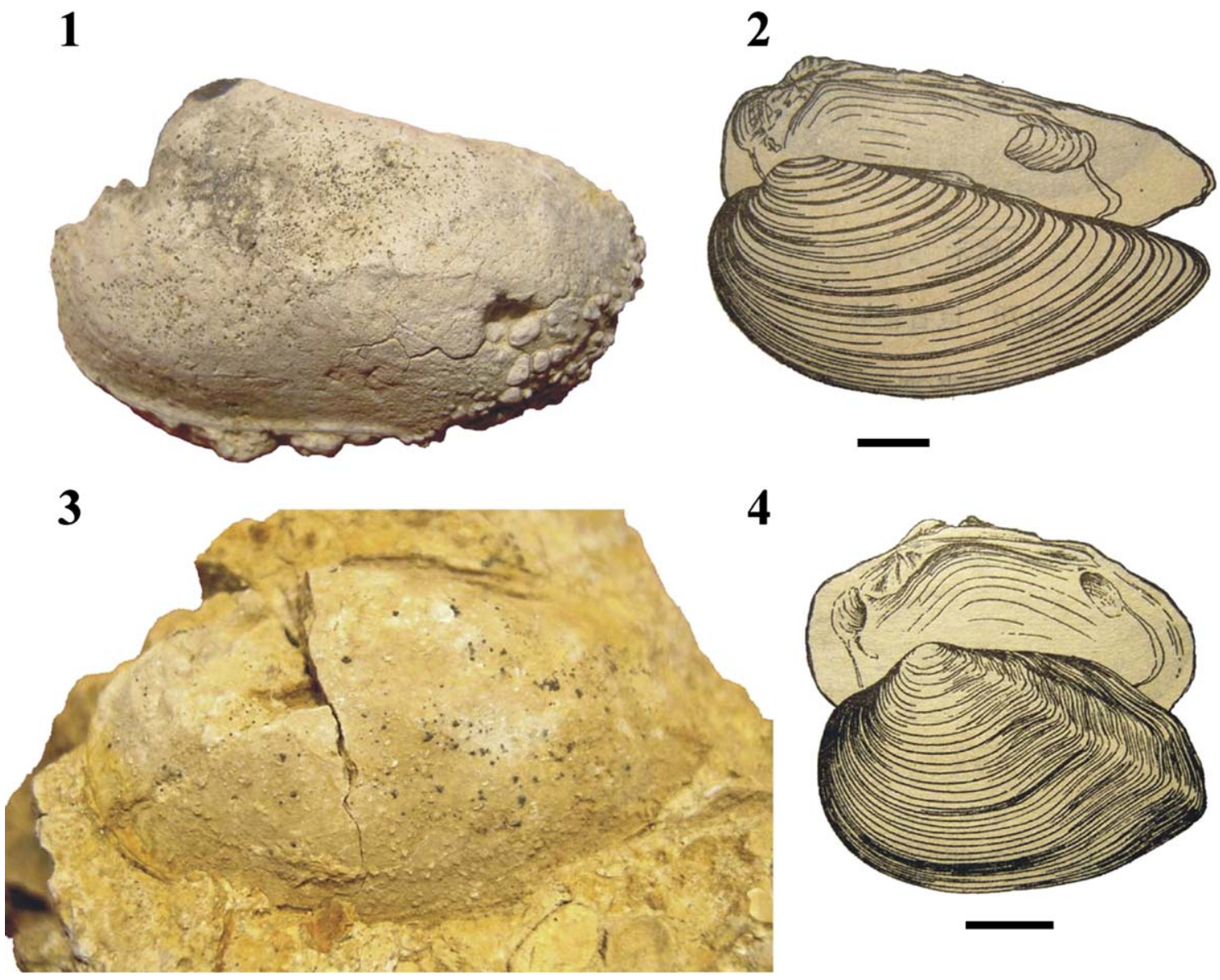

4

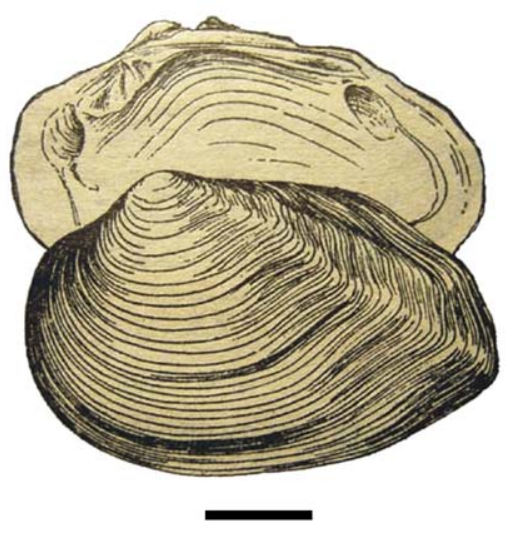

Fig. 8. Molluscs of the Nomogen Formation: 1, Cuneopsis sp. $(L=77 \mathrm{~mm})$ (Unionidae) inner mold, Bayan Ulan Beds, Unit 3 (Subeng, China); 2 , Recent Cuneopsis heudei (Heude) ( $L=71.5 \mathrm{~mm}$ ), South China (from Liu, 1979); 3, Acuticosta sp. ( $L=42 \mathrm{~mm}$ ) (Unionidae) inner mold, Bayan Ulan Beds, Unit 3 (Subeng, China); 4, Recent Acuticosta ovata (Simpson) ( $L=47.5 \mathrm{~mm})$, South China (from Liu, 1979). 
shallow water under an at least seasonally warm climate (Good, 2004, Table 1). The marginal lacustrine/fluvial sediments of unit 3 form the ideal habitat for these unionid molluscs (see Section 3.3).

\subsection{Amphibians and lizards}

Amphibians and lizards are represented in the Subeng section by a few, well preserved fragments of bones. The preservation of vertebrae neural arches or tooth tips shows that they underwent limited, low energy transport.

The anurans are represented by fourteen humerus distal ends ( 8 left and 6 right), one right ilium and two maxillae fragments (one left and one right), attributed to discoglossid frogs (Fig. 9.1-.4). One sacral vertebra could belong to a gobiatid frog (Fig. 9.5-.6). Discoglossidae are present in Asia already from the end of the Jurassic (Gao and Wang, 2001). Gobiatidae were present in Asia at least from the early Cretaceous and they were probably dominant among the Asian Cretaceous anurans (Rocek and Nessov, 1993), but this report would be their first Paleocene record.

The caudates (Fig. 9.7-.10) are represented in Subeng by an atlas and an isolated vertebra. The shape of the atlas is generalized among caudates (Estes, 1981), and it is therefore difficult to identify. However, it does not belong to a batrachosauroid (Duffaud, 2000). Otherwise, the vertebra presents salamandrid affinities (Duffaud, 2000). This family is known throughout Laurasia from the end of the Cretaceous (Rage and Hossini, 2000).

Six jaw fragments are attributed to the squamates (Fig. 9.11-.14), and five of them are identified as anguimorphs (Estes, 1983). From these, one incomplete right maxilla and two jaw fragments belong to an anguioid lizard and one left dentary fragment belongs to a varanoid lizard (Estes, 1983; Conrad, 2004). Anguimorphs are present in Asia since the end of the early Cretaceous (Alifanov, 1993). The anguioids are well known in the late Cretaceous and Paleogene of North America and probably appeared in Asia at about the same time (Alifanov, 2000).

\subsection{Mammals}

The mammal fossils from Subeng are fragile but well preserved and are thought to have undergone only limited transport. An overview of the mammal taxa observed at Subeng is given in Table 4. This fauna is closest to the Chinese mammal faunas from Bayan
Ulan and Nomogen (Nomogen Formation), and to the Gashato (Gashato Formation, Mbr I) and Naran Bulak faunas (Naran Bulak Formation, Naran and Zhigden $\mathrm{Mbr}$ ) in Mongolia. These four faunas are the classical faunas assigned to the Gashatan ALMA (Ting, 1998; Meng et al., 1998; Bowen et al., 2002). These correlations are especially supported by the presence of the arctostylopid Palaeostylops, the rodent-like Tribosphenomys and the taeniolabidioid multituberculates Lambdopsalis and Prionessus (Fig. 10), as they are exclusively known from the Gashatan.

The Subeng material contains a few remains of larger animals such as a calcaneum from Prodinoceras cf. plantigradum, and a femur and lower molar from Dissacus cf. serratus. However, the Subeng fauna is especially rich in small-bodied forms that are easily missed by surface collecting and are therefore often not or poorly known. The Subeng site is the first Paleocene site on the Mongolian Plateau that has been sampled for mammals by methodical screenwashing. A taphonomical bias is probably responsible for the high abundance of the small taxa. However, their study has already proven to be valuable for the understanding of the late Paleocene Asian mammal faunas and their paleobiogeograpical relations. We described from Subeng the carpolestid plesiadapiform Subengius mengi (Fig. 10.1-.2), currently the oldest Asian plesiadapiform (Smith et al., 2004). The nyctitheriid insectivore Asionyctia guoi from Subeng is the most completely known Asian nyctitheriid, and allowed us to group all Asian nyctitheriids in a new subfamily Asionyctiinae (Missiaen and Smith, 2005). Both taxa most probably descend from North American ancestors migrating into Asia, and for both taxa early dispersal scenarios during the middle Paleocene were proposed. The small neoplagiaulacid multituberculate Mesodmops dawsonae was described from the Bumbanian Wutu Formation in East China (Tong and Wang, 1994). It was suggested that Mesodmops is derived from the North American genus Mesodma, and migrated into Asia by the late Paleocene. Now a new species of Mesodmops is found at Subeng, differing from $M$. dawsonae by a slightly more primitive cusp formula, and by a more slender form. Our findings of Mesodmops from Subeng confirm the ideas expressed by Tong and Wang (1994, 1998), and represent the oldest Asian record of ptilodontoid multituberculates. In any case, the occurrence of these mammal taxa clearly indicate that mammal migration was not unidirectional from Asia towards North America as proposed by some authors (Beard, 2002). The identification of arctostylopid tarsal bones from Subeng also suggested faunal interchange between Asia 


\section{ARTICLE IN PRESS}

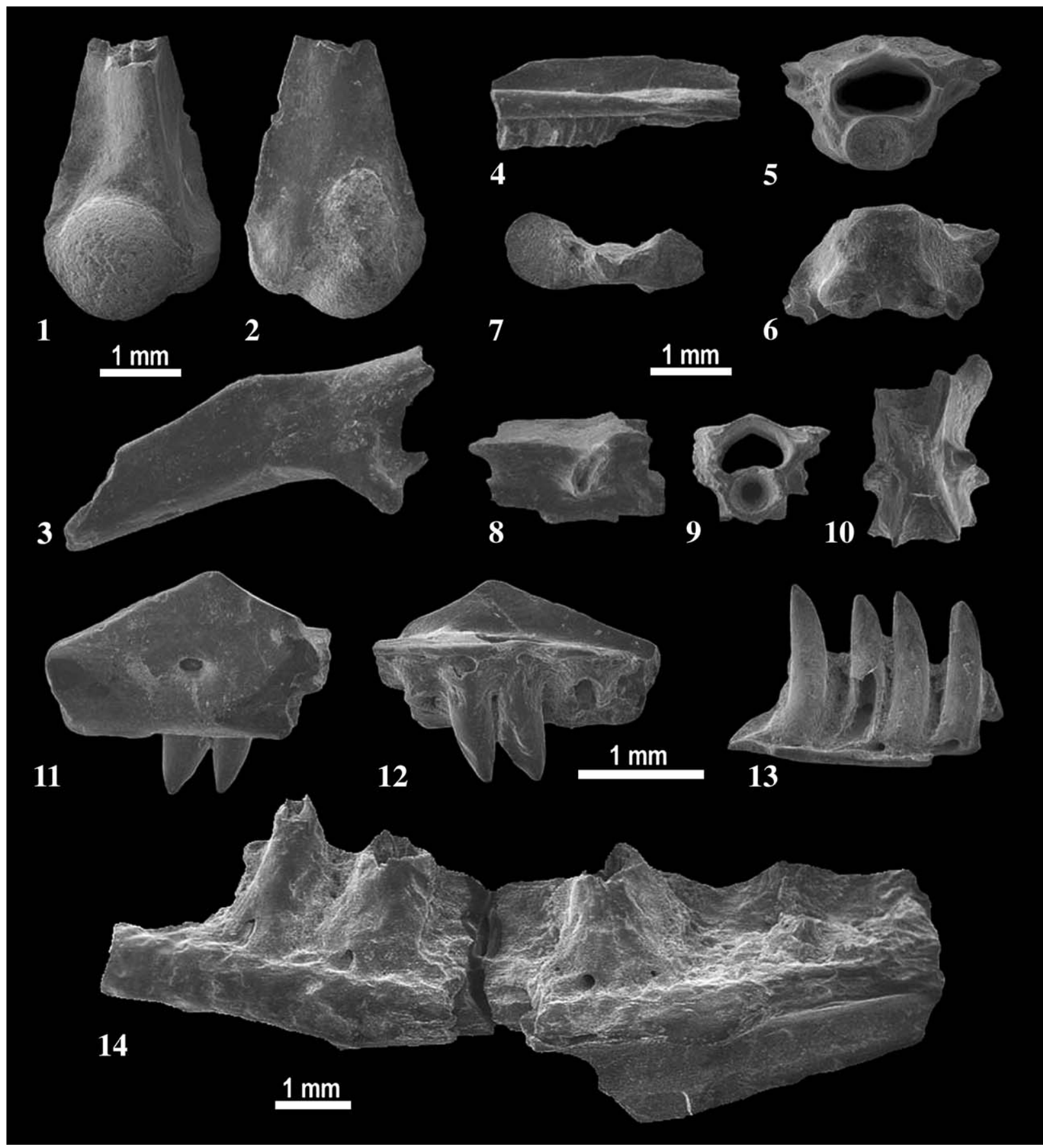

Fig. 9. Gashatan amphibians and lizards at Subeng: 1-10: Amphibians. 1-4: discoglossid frog indet:. humerus distal end in ventral and dorsal views, right ilium in lateral view, right maxilla in lingual view; 5-6: gobiatid frog?: sacral vertebra in anterior and ventral view; 7-10: Caudata indet: atlas in anterior view, vertebra in left lateral, anterior and ventral views. 11-14: Squamates. 11-13: Anguoidea indet.: maxilla in labial and lingual views, jaw fragment in lingual view; 14: Varanoidea indet.: jaw fragment in lingual view.

and North America, but weakened the support for Paleocene interchange between North and South American faunas (Missiaen et al., 2006).
An important number of other small mammals from Subeng represents an undocumented morphological and taxonomical diversity and their study may equally add 
Table 4

List of Gashatan mammal taxa at Subeng

Class Mammalia Linnaeus, 1785

Infraclass Allotheria Marsh, 1880

Order Multituberculata Cope, 1884

Superfamily Ptilondontoidea Cope, 1887

Family Neoplagiaulacidae Cope, 1887

Genus Mesodmops Tong and Wang, 1994

Mesodmops sp. nov.

Superfamily Taeniolabidoidea Granger and Simpson, 1929

Family Taeniolabididae Granger and Simpson, 1929

Genus Lambdopsalis Chow and Qi, 1978

Lambdopsalis bulla Chow and Qi, 1978

Genus Prionessus Matthew and Granger, 1925

cf. Prionessus lucifer

Infraclass Holotheria Wible et al., 1995

Cohort Placentalia Owen, 1837

Grandorder Gliriformes Wyss and Meng, 1996 Gliriformes indet.

Family Arctostylopidae Schlosser, 1923

Genus Palaeostylops Matthew and Granger, 1925 Palaeostylops iturus

Family Pseudictopidae Sulimski, 1969

Genus Pseudictops Matthew, Granger and Simpson, 1929 Pseudictops cf. lophiodon

Order Mixodontia Sych, 1971

Family Eurymylidae Dashzeveg and Russell, 1988

Genus Eomylus Dashzeveg and Russell, 1988

Eomylus cf. bayanulanensis Meng et al. 2005

Order Rodentiaformes Wyss and Meng, 1996

Family Alagomyidae Dashzeveg, 1990

Genus Tribosphenomys Meng, Wyss, Dawson and Zhai,

1994

Tribosphenomys cf. minutus

Grandorder Ferae Linnaeus, 1758

Order Cimolesta McKenna, 1975

Family Cimolestidae McKenna, 1975

Genus Tsaganius Russell and Dashzeveg, 1986

Tsganius sp.nov.

Order Carnivora Bowdich, 1821

Family Viverravidae Wortman and Matthew, 1899 Viverravidae indet.

Grandorder Lipotyphla Haeckel, 1866

Order Erinaceomorpha Gregory, 1910 Erinaceomorpha indet.

Order Soricomorpha Gregory, 1910

Family Nyctitheriidae Simpson, 1928 Nyctitheriidae sp.

Genus Asionyctia Missiaen and Smith, 2005 Asionyctia guoi Missiaen and Smith, 2005

Family Micropternodontidae Stirton and Rensberger, 1964

Genus Hyracolestes Matthew and Granger, 1925 Hyracolestes cf. ermineus

Grandorder Archonta Gregory, 1910

Order Proprimates Gingerich, 1989

Infraorder Plesiadapiformes Simons, 1972

Family Carpolestidae Simpson, 1935

Genus Subengius Smith, Van Itterbeeck and Missiaen, 2004 Subengius mengi Smith, Van Itterbeeck and Missiaen, 2004

Grandorder Ungulata Linnaeus, 1766

Order Dinocerata Marsh, 1873

Family Uintatheriidae Flower, 1876
Table 4 (continued)

Genus Prodinoceras Matthew, Granger and Simpson, 1929 Prodinoceras sp.

Order Mesonychia Matthew, 1937

Family Mesonychidae Cope, 1875

Genus Dissacus Cope, 1881

Dissacus cf. serratus (Chow and Qi, 1978)

significant new insight into the mammal faunas of the Paleocene-Eocene transition in Asia.

\section{Age of the Subeng site}

From unit 1, only palynomorphs were retrieved, and these clearly indicate a Maastrichtian age, agreeing with the late Cretaceous age proposed for the Iren Dabasu Formation (BGMRNMAR, 1991).

The presence of different fossil groups in both units of the Nomogen Formation allows multiple independent correlations and dating. The unit 2 palynomorphs indicate a Paleocene age based on the dominance of Normapolles, the limited occurrence of relict Cretaceous and modern taxa. Charophyte data suggest a correlation to the late Paleocene Naran Member in Mongolia, while ostracod data show affinities to the Naran Member and to the middle to upper levels of the Funing Group in the late Paleocene of East China. Mammal biostratigraphy clearly places the Subeng fauna in the Gashatan ALMA, correlating it to the nearby Bayan Ulan and Nomogen faunas also from the Nomogen Formation, to the Naran, Zhigden and Gashato faunas in Mongolia, and to the Lower Lingcha fauna in South China (Ting, 1998; Bowen et al., 2002).

A major advance to date the Gashatan faunas was the absolute dating of the Lingcha Formation (Bowen et al., 2002). The Gashatan Lower Lingcha fauna occurs somewhat below the chron $\mathrm{C} 25 \mathrm{n} / \mathrm{C} 24 \mathrm{r}$ reversal, and the Bumbanian Upper Lingcha fauna was collected close to the minimum of the $\delta \mathrm{C}^{13}$ excursion (Bowen et al., 2002; Ting et al., 2003). This showed that at least part of the Gashatan faunas are late Paleocene, and part of the Bumbanian faunas are early Eocene. The exact limit between the two ALMAs could not be located, but is situated in a $900 \mathrm{kyr}$ uncertainty window containing the Paleocene-Eocene boundary (PEB). More recently, Bowen et al. (2005) made a composite section based on different late Paleocene and early Eocene sections from the Erlian Basin, and correlated this to the Geomagnetic Polarity Timescale. They extend the upper limit of the Gashatan into chron C24r, and possibly even very near to the $\mathrm{PEB}$, and the lower limit of the Gashatan into chron C25r or even C26n. This suggests 


\section{ARTICLE IN PRESS}

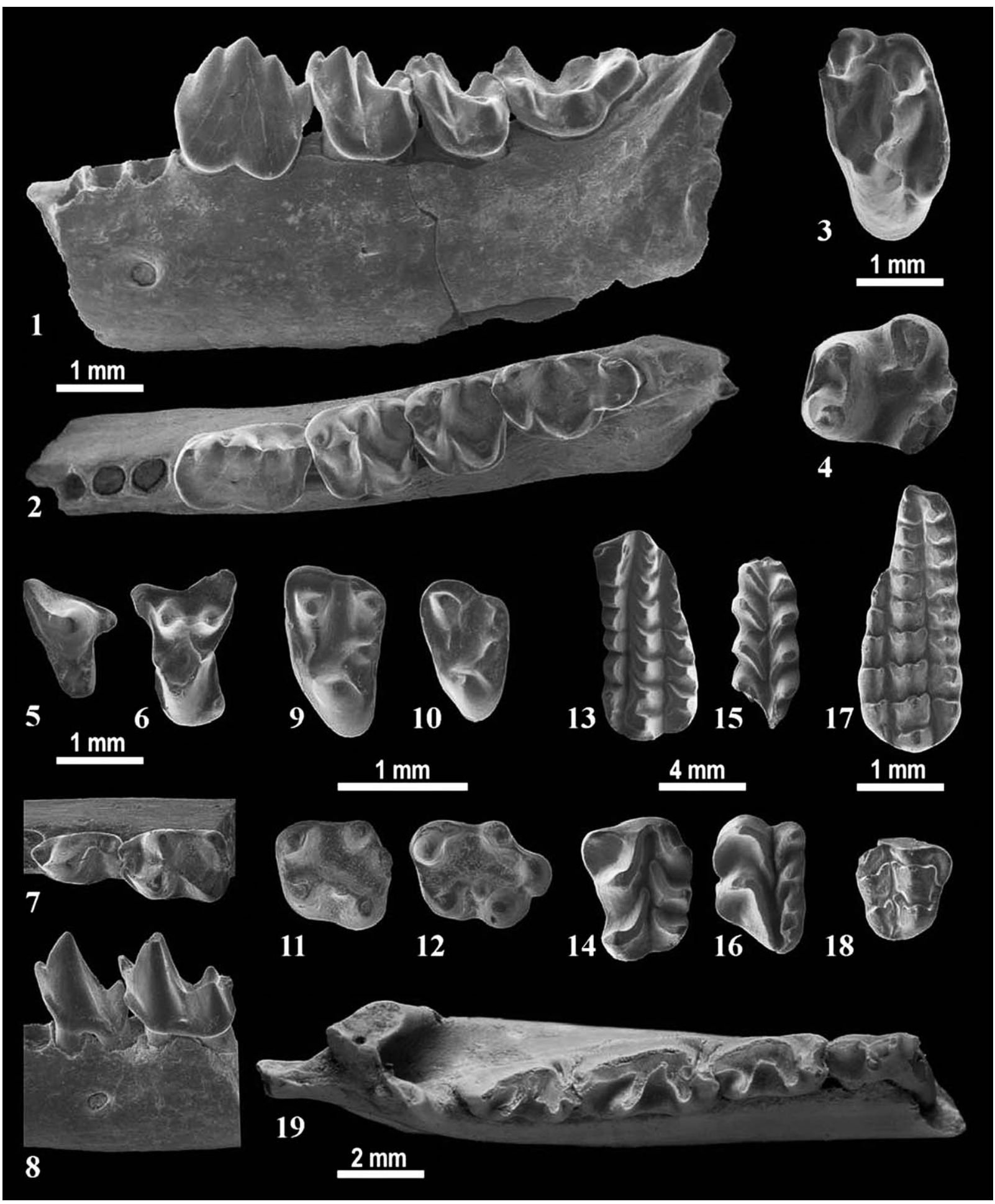

Fig. 10. Gashatan mammals at Subeng: 1-2: Subengius mengi: p4-m3 in labial and occlusal view; 3-4: Eomylus cf. bayanulanensis: M2 and m1 in occlusal view; 5-8: Asionyctia guoi: P4 and M1 in occlusal view, p4-m1 in occlusal and labial view; Tribosphenomys cf. minutus: M2, M3, m2 and $\mathrm{m} 3$ in occlusal view; 13-16: Lambdopsalis bulla: M1, M2, $\mathrm{m} 1$ and $\mathrm{m} 2$ in occlusal view; 17-18: Mesodomops sp.nov.: M1 and M2 in occlusal view; 19: Palaeostylops iturus: $\mathrm{p} 4-\mathrm{m} 3$ in occlusal view. 
that the Gashatan ALMA correlates to the complete Clarkforkian and the upper Tiffanian in North America (Gingerich, 2003), and to much of the Thanetian in Europe (Gradstein et al., 2004).

\section{Depositional environments and palaeoecology}

As suggested also by the sedimentological data and corroborated by abundance of Botryococcus, we interpret unit 1 as a wetland environment, although the scarcity of spores is enigmatic. The highly abundant bisaccate gymnosperm pollen as well as Ephedripites are interpreted as allochtonous representatives of a relatively nearby upland vegetation.

During the Paleocene, the Subeng region was a fluvio-lacustrine environment in a dry region (Fig. 11) (Song and Zhang, 1990; Meng et al., 1998). The lake was stratified with an anoxic hypolimnion resulting in the preservation of the fine lamination and of organicrich layers within the distal lake sediments. This original bedding was mostly lost in the proximal lake sediments by bioturbation of the benthic community. The lake ecosystem contained a rich flora of aquatic plants and algae (charophytes, Botryococcus, Pediastrum) and a rich fauna of ostracods, fish (represented by isolated teeth and vertebrae) and gastropods.

The lake margin is characterised by a system of minor channels and rivers. Within the channel deposits, articulated bivalves occur frequently, indicating calm, clean and well oxygenated waters, and suggesting climate conditions similar to present-day southern China and Vietnam. This zone was vegetated by typical lowland plants like ferns, Taxodiaceae and Plicatopollis plicatus. Many of the pollen types from Subeng (Ginkgocycadophytes, Taxodiaceapollenites, Castaneapollenites, Plicatopollis, Caryapollenites) belong to groups of tree- or shrub-like plants. Moreover, although the biological affinities of the Normapolles pollen from Subeng are uncertain, all recent findings of fossil flowers with attached Normapolles pollens are thought to be members of the Fagales (Sims et al., 1999; Friis et al., 2003), which are also dominantly tree-shaped. The high abundance of ferns is indicative of shady, humid conditions, and may represent the undergrowth in a

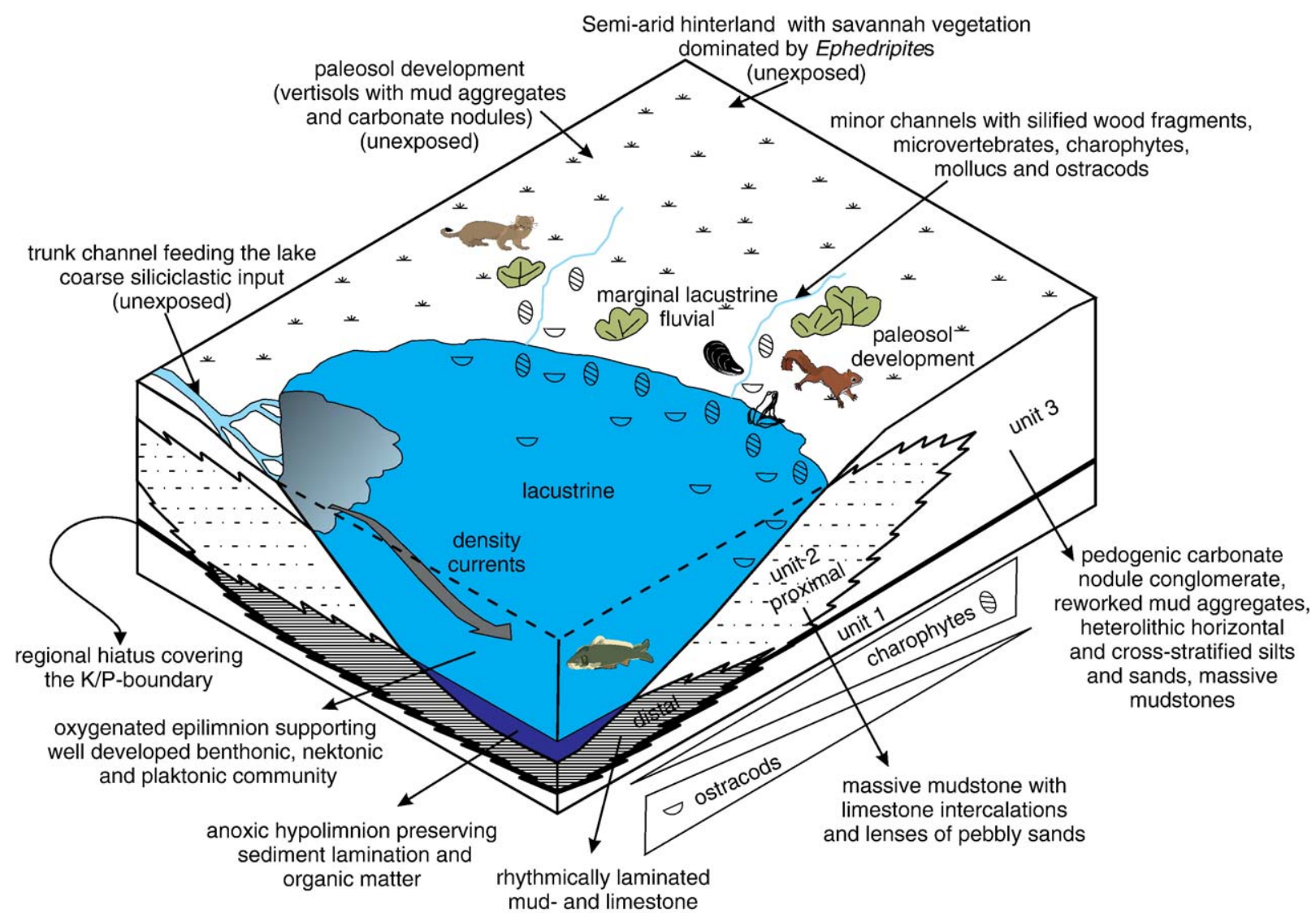

Fig. 11. Paleoenvironmental reconstruction of the Subeng area during the late Paleocene. 
relatively woody environment. Subengius mengi is a member of the arboreal Plesiadapiformes and therefore certainly seems fit to live in a more forested environment. Among the other small mammals from Subeng, at least also for the nyctitheriids an arboreal mode of life cannot be excluded (Hooker, 2001).

Typical dryland vegetation is hardly represented in the pollen assemblage of the Nomogen formation at Subeng, suggesting a remote origin. The Bayan Ulan beds of the Nomogen Formation at Subeng contain calcrete nodules and mud aggregates, which are generally formed in dryland settings under climates that are at least seasonally hot and dry. However, these calcretes and mud pebbles are not in situ, but were reworked from more distant, unexposed environments. Equally, at Subeng, only limited development of red coloured palaeosols occurred and no gypsum or other evaporites were observed.

Contrastingly, in the nearby Bayan Ulan site the vivid red colour of the sediments was what gave this site its name, and in the Nomogen site the fossils are found in layers containing gypsum and celestite concretions (Russell and Zhai, 1987; Meng et al., 1998). Further away, in western Inner Mongolia, the Nomogen Formation is characterized by gypsum intercalations, with abundant pollen from upland vegetation and up to $30 \%$ xerophytic Ephidripites (Song and Zhang, 1990; Song, 1996). Therefore, Central Asia has been considered to have an open shrubbery or savanna vegetation in a relatively arid subtropical climate, with only small, dispersed woodlots and without arboreal mammals (Meng et al., 1998). Consequently, the Paleocene Central Asian environments were considered distinctly different from the more humid and forested conditions in southern and eastern areas of China and in Europe and North America (Gingerich, 1989; Song and Zhang, 1990; Meng et al., 1998).

Following our interpretation, the Subeng area represents a locally extensive, more humid woodland on this drier, more open Mongolian Plateau, with both a flora and fauna distinctly different from other Gashatan sites from Central Asia. Most notable are, the Paleocene records of plesiadapiforms and ptilodontoid multituberculates at Subeng, immigrants from North America and the first and oldest Asian members of groups previously only known from the early Eocene Wutu fauna in eastern China (Tong and Wang, 1998). This may suggest that the local palaeoenvironment at Subeng was more similar to the humid, forested conditions in North America and in eastern and southern China than was the case for any other Gashatan fauna known to date.

\section{Conclusions}

The multidisciplinary study of the Subeng section presented here is the first of its kind in this region and it is a first step into a more complete environmental picture of the Mongolian Plateau.

Based on both sedimentological and palynological data the Iren Dabasu Formation in Subeng is characterised as a wetland environment. Pollen data further confirm a Maastrichtian age for these deposits, and its place on the boundary of the northwestern ('Normapolles') and northeastern ('Aquilapollenites') Chinese palynological provinces.

The Nomogen Formation from Subeng is characterised by the presence of abundant and diverse fossil groups. Ostracod, charophyte, pollen and mammal data together strongly suggest a late Paleocene age, placing it in the Gashatan ALMA. Both sedimentological and palaeontological data suggest a fluvio-lacustrine, relatively humid local environment in a warm to subtropical and semi-arid region. The local flora is more woody and closed than elsewhere in this region. The Subeng area represents an isolated woodland on the dry Mongolian Plateau. The mammal fauna reflects these differences and shows a number of relatives to mammals from the more humid eastern Chinese biotic province, who are known to be North American immigrants. The Subeng mammals thus form a link between the forest adapted faunas in North America and in eastern China Possibly the woody local palaeoenvironment at Subeng was more suitable for the North American immigrants. Therefore we regard the Subeng mammal assemblage as a somewhat peculiar Gashatan fauna, presenting interesting affinities to faunas from both eastern China and North America.

\section{Acknowledgements}

The fieldwork in Inner Mongolia was only possible through the efforts of Shao Qing Long, Li Hong and Ning Pei Ji, and of Pierre Bultynck, Pascal Godefroit, Etienne Steurbaut, and Hugo De Potter. At the IRSNB, Suzanne Watrin picked out the fossils, and Julien Cillis produced the SEM photographs. We are especially grateful to Philippe Gerrienne who prepared and studied the silicified wood fragments from Subeng. Financial support for this project has been provided by the Institute for the Promotion of Innovation through Science and Technology in Flanders (to PM), by Research Project MO/36/011 (to TS) and Excavation Project BL/ $36 / \mathrm{C} 12$ of the Belgian Federal Science Policy Office and grants 04-1-P25-053 “Origin and evolution of 
biosphere" and 04-1-06-002 "Groundlines of biodiversity preservation in Russia" of the Programme of the Presidium of the Russian Academy of Sciences. PM is a Research Assistant of the Fund for Scientific Research - Flanders, Belgium (FWO - Vlaanderen) and AF is a FRIA grant holder.

\section{References}

Alifanov, V.R., 1993. Some peculiarities of the Cretaceous and Palaeogene lizard faunas of the Mongolian People's Republic. Darmstädter Beiträge zur Naturgeschichte 3, 9-13.

Alifanov, V.R., 2000. The fossil record of Cretaceous lizards from Mongolia. In: Benton, M.J., Shishkin, M.A., Unwin, D.M., Kurochkin, E.N. (Eds.), The Age of Dinosaurs in Russia and Mongolia. Cambridge University Press, Cambridge, pp. 368-389.

Batten, D.J., 1996. Chapter 7C. Colonial Chlorococcales. In: Jansonius, J., McGregor, D.C. (Eds.), Palynology: Principles and Applications. AASP foundation, pp. 191-203.

Batten, D.J., Grenfell, H.R., 1996. Chapter 7D. Botryococcus. In: Jansonius, J., McGregor, D.C. (Eds.), Palynology: Principles and Applications. AASP foundation, pp. 205-214.

Beard, K.C., 1998. East of Eden: Asia of important center of taxonomic origination in mammalian evolution. Bulletin of Carnegie Museum of Natural History 34, 5-39.

Beard, K.C., 2002. Paleontology: east of Eden at the Paleocene/Eocene boundary. Science 295, 2028-2029.

Berkey, C.P., Morris, F.K., 1927. Natural History of Central Asia, Volume II. Geology of Mongolia, I. The American Museum of Natural History, New York. 475 pp.

Bowen, G.J., Clyde, W.C., Koch, P.L., Ting, S., Alroy, J., Tsubamoto, T., Wang, Y., Wang, Y., 2002. Mammalian dispersal at Paleocene/ Eocene boundary. Science 295, 2062-2065.

Bowen, G.J., Koch, P.L., Meng, J., Ye, J., Ting, S., 2005. Age and correlation of fossiliferous Late Paleocene-Early Eocene strata of the Erlian Basin, Inner Mongolia, China. American Museum Novitates 3474, 1-26.

Bultynck, P., Dhondt, A.V. (Eds.), 1998. The Sino-Belgian Dinosaur Expedition in Inner MongoliaBulletin van het Koninklijk Belgisch Instituut voor Natuurwetenschappen, vol. 68 (supplement). Brussel, 70 pp.

Bultynck, P., Dhondt, A.V. (Eds.), 1999. The Sino-Belgian Dinosaur Expedition in Inner MongoliaBulletin van het Koninklijk Belgisch Instituut voor Natuurwetenschappen, vol. 69 (supplement). Brussel, 47 pp

Bultynck, P., Dhondt, A.V. (Eds.), 2001. The Sino-Belgian Dinosaur Expedition in Inner MongoliaBulletin van het Koninklijk Belgisch Instituut voor Natuurwetenschappen, 71 (supplement). Brussel, 70 pp.

Bureau of Geology and Mineral Resources of Nei Mongol autonomous region, 1991. Regional Geology of Nei Mongol (Inner Mongolia) Autonomous Region, People's Republic of China. Geological Memoirs series, vol. 1, 25. Geological Publishing House, Bejing. $725 \mathrm{pp}$

Chlonova, A.F., 1961. Spores and pollen from the upper half of the Upper Cretaceous of the eastern part of the East Siberian Lowland. Transactions of the Institute of Geology and Geophysics SB AS USSR 7, 1-138.

Conrad, J.L., 2004. Skull, mandible, and hyoid of Shinosaurus crocodilurus Ahl (Squamata, Anguimorpha). Zoological Journal of the Linnean Society 141 (3), 399-434.
Corillion, R., 1975. Flore des Charophytes (Characées) du Massif Armoricain et des contrées voisines d'Europe occidentale. Flore et Végétation du Massif Armoricain, IV. Jouve Éditeurs, Paris, $216 \mathrm{pp}$.

Duffaud, S., 2000. Les Faunes d'Amphibiens du Crétacé Supérieur à l'Oligocène Inférieur en Europe: Paléobiodiversité, Évolution, Mise en Place. Laboratoire de Paléontologie, Muséum National d'Histoire Naturelle, Paris, France. 221 pp.

Estes, R., 1981. Encyclopedia of Paleoherpetology, Part 2: Gymnophiona, Caudata. Gustav Fischer Verlag, New York. 115 pp.

Estes, R., 1983. Encyclopedia of Paleoherpetology, Part 10A: Sauria terrestria, Amphisbaenia. Gustav Fischer Verlag, New York. 249 pp.

Feist, M., Grambast-Fessard, N., 1982. Clé de détermination pour les genres de charophytes. Paléobiologie Continentale 13, 1-28.

Frederiksen, N.O., 1985. Review of Early Tertiary sporomorph paleoecology. AASP Contribution Series 15, 1-92.

Friis, E.M., Pedersen, K.R., Schönenberger, J., 2003. Endressianthus, a new Normapolles-producing plant genus of fagalean affinity from the Late Cretaceous of Portugal. International Journal of Plant Sciences 164 (S5), S201-S223.

Gao, K., Wang, Y., 2001. Mesozoic anurans from Liaonong Province, China, and phylogenetic relationships of archaeobatrachian anuran clades. Journal of Vertebrate Paleontology 21 (3), 460-476.

Gingerich, P.D., 1989. New Earliest Wasatchian mammalian fauna from the Eocene of northwestern Wyoming: composition and diversity in a rarely sampled high-floodplain assemblage. University of Michigan Papers on Paleontology 28, 1-97.

Gingerich, P.D., 2000. Paleocene/Eocene boundary and continental vertebrate faunas of Europe and North America. GFF 122, 57-59.

Gingerich, P.D. (Ed.), 2001. Paleocene-Eocene stratigraphy and biotic change in the Bighorn and Clarks Fork Basins, Wyoming. Papers on Palaeontology, vol. 33. University of Michigan, Ann Arbor. 198 pp.

Gingerich, P.D., 2003. Mammalian responses to climate change at the Paleocene-Eocene boundary: Polecat Bench record in the northern Bighorn Basin, Wyoming. Geological Society of America Special Paper 369, 463-478.

Good, S.C., 2004. Paleoenvironmental and paleoclimatic significance of freshwater bivalves in the Upper Jurassic Morrison Formation, Western Interior, USA. Sedimentary Geology 167 (3-4), $163-176$.

Gradstein, F.M., Ogg, J.G., Smith, A.G. (Eds.), 2004. A Geological Time Scale 2004. Cambridge University Press, Cambridge. $610 \mathrm{pp}$.

Guan, S., 1988. Paleocene non-marine ostracods in China. In: Hanai, T., Ikeya, N., Ishizaki, K. (Eds.), Evolutionary Biology of Ostracoda, Its Fundamentals and Applications. Elsevier, Tokyo, pp. 1147-1152.

He, J., Van Nieuwenhuise, D.S., Swain, F.M., 1988. Biostratigraphy of Paleogene ostracoda from East China. In: Hanai, T., Ikeya, N., Ishizaki, K. (Eds.), Evolutionary Biology of Ostracoda, Its Fundamentals and Applications. Elsevier, Tokyo, pp. 1153-1161.

Herngreen, G.F.W., Chlonova, A.F., 1981. Cretaceous microfloral provinces. Pollen et Spores XXIII (3-4), 441-555.

Herngreen, G.F.W., Kedves, M., Rovnina, L.V., Smirnova, S.B., 1996. Cretaceous palynofloral provinces: a review. In: Jansonius, J., McGregor, D.C. (Eds.), Palynology: Principles and Applications. American Association of Stratigraphic Palynologists Foundation, pp. 1157-1188.

Hooker, J.J., 1998. Mammalian faunal change across the PaleoceneEocene transition in Europe. In: Aubry, M.-P., Lucas, S.G., Berggren, W.A. (Eds.), Late Paleocene-Early Eocene Climatic and 
Biotic Events in the Marine and Terrestrial Records. Columbia University Press, New York, pp. 428-450.

Hooker, J.J., 2001. Tarsals of the extinct insectivoran family Nyctitheriidae (Mammalia): evidence for archontan relationships. Zoological Journal of the Linnean Society 132, 501-529.

Hou, Y., Chen, T., Yang, H., Ho, J., Zhou, Q., Tian, M., 1982. Cretaceous-Quaternary Ostracod Fauna from Jiangsu. Geological Publishing House, Beijing. 298 pp.

Huang, R., Zhang, J., 1984. Late Cretaceous and Paleogene charophytes from the Sanshui Basin of Guangdong. Bulletin of the Nanjing Institute of Geology and Palaeontology, Academia Sinica 9 (9), 169-210.

Huang, R., Zhao, Z., 1989. Charophytes from the Taizhou Formation and the first member of Funing Formation, North Jiangsu Basin in addition to their ages. Bulletin of the Nanjing Institute for Geology and Paleontology of the Academia Sinica, pp. 111-127.

Karczewska, J., Ziembinska-Tworzydlo, M., 1972. Lower Tertiary Charophyta from the Nemegt Basin, Gobi Desert. Palaeontologia Polonica 27, 51-81.

Khand, E., 1976. Some new ostracod species from the Upper Cretaceous and Paleogene deposits in the south of the Mongolian Republic. The Joint Soviet-Mongolian Palaeontological Expedition, Transactions 3, 151-159.

Khand, Y., 1987. Late Cretaceous and Early Paleogene ostracods of Mongolia and their stratigraphic significance. Autoreview. Akademia Nauk CCCP, Paleontologicheskii Institut, Moscow. $22 \mathrm{pp}$.

Khand, Y., 2000. The origins of modern nonmarine ostracod faunas: evidence from the Late Cretaceous and Early Palaeogene of Mongolia. Hydrobiologia 419, 119-124.

Krause, D.W., Maas, M.C., 1990. The biogeographic origin of the Late Paleocene-Early Eocene mammalian immigrants to the Western Interior of North America. Bulletin of the Geological Society of America Special Paper 243, 71-105.

Lea, I., 1868. Descriptions of four new species of exotic Unionidae. Proceedings of the Academy of Natural Sciences of Philadelphia 20, 150 .

Liu, Y., 1979. Economic Fauna of China (Freshwater Molluscs). Hyayu Center for Environmental Services, Beijing. 134 pp. (in Chinese).

Liu, J., 1987. Late Cretaceous-Tertiary charophytes from the Shalamulun area of Inner Mongolia. Professional Papers of Stratigraphy and Palaeontology 19, 129-154, 6 pl.

Lu, H., 1997. On charophyte genera named by Chinese authors. Acta Micropalaeontologica Sinica 14 (4), 391-404.

Mack, G.H., James, C.W., Monger, C.H., 1993. Classification of palaeosols. Geological Society of America Bulletin 105, 129-136.

Magioncalda, R., Dupuis, C., Smith, T., Steurbaut, E., Gingerich, P.D., 2004. Paleocene-Eocene carbon isotope excursion in organic carbon and pedogenic carbonate: direct comparison in a continental stratigraphic section. Geology 32, 553-556.

Martinson, G.G., 1982. Upper Cretaceous molluscs of Mongolia (systematics, stratigraphy, taphonomy). The Joint Soviet-Mongolian Palaeontological Expeditions, Transactions 17, 1-83.

Meng, J., Zhai, R., Wyss, A.R., 1998. The Late Paleocene Bayan Ulan fauna of Inner Mongolia, China. Bulletin of Carnegie Museum of Natural History 34, 148-185.

Meng, Q., Hu, J., Jin, J., Zhang, Y., Xu, D., 2003. Tectonics of the Late Mesozoic wide extensional basin system in the China-Mongolian border region. Basin Research 15, 397-415.

Missiaen, P., Smith, T., 2004. The Late Paleocene site of Subeng (Inner Mongolia, China): completing and challenging mammal biogeography in Asia. Journal of Vertebrate Paleontology 24, 95A.
Missiaen, P., Smith, T., 2005. A new nyctitheriid insectivore from Inner Mongolia (China) and its implications for the origin of the Asian nyctitheriids. Acta Palaeontologica Polonica 50, 513-522.

Missiaen, P., Smith, T., Guo, D.-Y., Bloch, J.I., Gingerich, P.D., 2006. Asian Gliriform origin for arctostylopid mammals. Naturwissenschaften 93, 407-411.

Ni, X., Wang, Y., Hu, Y., Chuankui, L., 2004. A euprimate skull from the Early Eocene of China. Nature 427, 65-68.

Platt, N.H., Wright, V.P., 1991. Lacustrine carbonates: facies models, facies distributions and hydrocarbon aspects. In: Anadon, P., Cabrera, L., Kelts, K. (Eds.), Lacustrine Facies Analysis. International Association of Sedimentologists Special Publication. Blackwell Scientific Publications, Oxford, pp. 57-74.

Polumiskova, L.A., Terekhova, E.K., Bliakhova, S.M., Ponomarenko, Z.L., 1966. Change in floras during the Upper Cretaceous and Paleogene time on the territory of Kazakhstan. In: Nejshtadt, M.I. (Ed.), The importance of palynological analysis for the stratigraphic and paleofloristic investigations. Publishing House "Nauka", Moscow, pp. 154-158.

Ponomarenko, Z.L., 1966. The age and paleogeographical environments of bauxite formation in Kazakhstan. In: Nejshtadt, M.I. (Ed.), The importance of palynological analysis for the stratigraphic and paleofloristic investigations. Publishing House "Nauka", Moscow, pp. 148-154.

Rage, J.-C., Hossini, S., 2000. Les Amphibiens du Miocène moyen de Sansan. Mémoires du Muséum national d'Histoire naturelle 183, 177-217.

Rocek, Z., Nessov, L.A., 1993. Cretaceous anurans from Central Asia. Palaeontographica 226, 1-54 (Abt A).

Russell, D.E., Zhai, R., 1987. Paleogene mammals of Asia. Mémoires du Muséum National d'Histoire Naturelle, Paris (Série C) 52, $1-490$.

Rust, B.R., Nanson, G.C., 1989. Bedload transport of mud as pedogenic aggregates in modern and ancient rivers. Sedimentology 36, 291-306.

Samoilovich, S.R., 1961. The Maastrichtian. Trudy VNIGRI 177, 316-329.

Samoilovich, S.R., 1977. New outlines of floristic division into districts of the northern hemisphere throughout the Late Senonian. Paleontologicheskii Zhurnal 3, 118-127.

Simpson, C.T., 1900. Synopsis of the naiades, or pearly fresh-water mussels. Proceedings of the United States National Museum 22 (1205), 501-1044.

Sims, H.J., Herendeen, P.S., Lupia, R., Christopher, R.A., Crane, P.R., 1999. Fossil flowers with Normapolles pollen from the Upper Cretaceous of southeastern North America. Review of Palaeobotany and Palynology 106, 131-151.

Smith, T., 2000. Mammals from the Paleocene-Eocene transition in Belgium (Tienen Formation, MP 7): palaeobiogeographical and biostratigraphical implications. GFF 122, 148-149.

Smith, T., Van Itterbeeck, J., Missiaen, P., 2004. Oldest Plesiadapiform (Mammalia, Proprimates) of Asia and its paleobiogeographical implication for faunal interchange with North America. Comptes Rendus Palevol 3 (1), 43-52.

Song, Z., 1996. Early Tertiary Normapolles and related palynomorphs of China (I). Taiwania 41 (1), 53-67.

Song, Z., Huang, F., 1997. The boundaries between the Southern Laurasian and Northern Gondwana Provinces and the Aquilapollenites and Normapolles palynofloras in East Asia. Cretaceous Research 18, 1-15.

Song, Z., Zhang, D., 1990. Geological age of the Caomuhao Gypsum Mine in Otog Banner, Nei Mongol with review of research on fossil 
proteaceous pollen in China. Acta Palaeontologica Sinica 29 (3), 257-269 (In Chinese, English summary).

Sun, X., 1979. Palynofloristic investigation on the Late Cretaceous and Paleocene of China. Acta Phytotaxonomica Sinica 17 (3), $8-23$.

Szczechura, J., 1971. Fresh-water ostracoda from the Paleocene of the Nemegt Basin, Gobi Desert, Mongolia. Palaeontologia Polonica 25, 85-97.

Tang, L., Di, H., 1991. Fossil charophytes from Qaidam Basin, Qinghai. Seris on Stratigraphy and Palaeontology of Oil and Gas Bearing Areas in China. Scientific and technical Documents Publishing House. p1-188 pp.

Tappan, H., 1980. Charophytes and Umbellinaceans, the Paleobiology of Plant Protists. Freeman and Cy, San Francisco, pp. 913-963.

Ting, S., 1998. Paleocene and Early Eocene land mammal ages of Asia. Bulletin of the Carnegie Museum of Natural History 34, 124-147.

Ting, S., Bowen, G.J., Koch, P.L., Clyde, W.C., Wang, Y., McKenna, M.C., 2003. Biostratigraphic, chemostratigraphic and magnetostratigraphic study across the Paleocene-Eocene boundary in the Hengyang Basin, Hunan, China. Geological Society of America Special Paper 369, 521-535.

Tong, Y., Wang, J., 1994. A new neoplagiaulacid multituberculate (Mammalia) from the lower Eocene of Wutu Basin, Shandong. Vertebrata PalAsiatica 32, 275-284.
Tong, Y., Wang, J., 1998. A preliminary report on the Early Eocene mammals of the Wutu fauna, Shandong Province, China. Bulletin of the Carnegie Museum of Natural History 34, 186-193.

Van Itterbeeck, J., Bultynck, P., 2004. Non-marine ostracods from the Paleocene Subeng mammal site, Inner Mongolia, P.R. China, taxonomy and biostratigraphy. Bulletin van het Koninklijk Belgisch Instituut voor Natuurwetenschappen 74 (supplement), 155-163.

Van Itterbeeck, J., Horne, D.J., Bultynck, P., Vandenberghe, N., 2005. Stratigraphy and palaeoenvironment of the dinosaur-bearing Upper Cretaceous Iren Dabasu Formation (Inner Mongolia, People's Republic of China). Cretaceous Research 26, 699-725.

Wang, D.-N., Sun, X.-Y., Zhoa, Y.-N., 1990. Late Cretaceous to Tertiary Palynofloras in Xinjiang and Qinghai, China. Review of Palaeobotany and Palynology 65, 95-104.

Wang, Y., Hu, Y., Chow, M., Li, C., 1998. Chinese Paleocene mammal faunas and their correlation. Bulletin of Carnegie Museum of Natural History 34, 89-123.

Xinlun, Wang, S., Huang, R., Yang, C., Li, H., 1978. Early Tertiary Charophytes from Coastal Region of Bohai. Science Press, Beijing. $49 \mathrm{pp}$.

Wang, Z., Lu, H., 1982. Classification and evolution of Clavatoraceae, with notes on their distribution in China. Bulletin of the Nanjing Institute for Geology \& Paleontology of the Academia Sinica 4, 77-104. 